\title{
Don't Daze, Phase, or Lase Me, Bro! Fourth Amendment Excessive-Force Claims, Future Nonlethal Weapons, and Why Requiring an Injury Cannot Withstand a Constitutional or Practical Challenge
}

\author{
Douglas B. McKechnie*
}

\section{INTRODUCTION}

Imagine a person in agonizing pain. He cannot move. He cannot remember where he is or what he was doing before this moment. He cannot focus on anything but this piercing, all-encompassing sensation and his inability to control his body. Just as he begins to come around, the pain explodes again.

Gradually, the feelings subside. He hears shouting as he regains his bearings and realizes he is in handcuffs. Slowly, he begins to piece together what happened.

He approached a stop sign in an unfamiliar part of town. Out of the corner of his eye, he saw a police officer turn on her lights and siren. After stopping his car, he got out to ask the officer for directions. As he approached her car, she jumped out, pointed an unusual-looking rifle at him, and ordered him to stop. Unbeknownst to him, his car was similar to one that had recently been used in a bank robbery. Confused, he continued to approach the officer's car, and she discharged her weapon. He remembers struggling to stay on his feet and escape the weapon's reach. As he struggled, the police officer discharged her weapon again.

As a result of his experience, he files a lawsuit alleging that the officer used more force than was necessary under the circumstances.

Assistant Professor of Law, Appalachian School of Law; J.D., University of Pittsburgh School of Law; B.A., Ohio University. The author would like to thank Professor Patrick Baker, Professor Anne Rife, and Saundra Latham for commenting on earlier drafts of this article. The author would also like to thank Eugene Belenitsky for his invaluable research assistance. Finally, the author would like to thank the Southeastern Association of Law Schools for the opportunity to present this article and receive valuable feedback. 
The court, however, dismisses the lawsuit because the weapon did not inflict more than an indeterminate amount of injury.

The Supreme Court has articulated a test for analyzing Fourth Amendment excessive-force claims that focuses solely on the reasonableness of the force used by a police officer when detaining a suspect. $^{1}$ Nonetheless, some circuit and district courts have added an additional requirement. Though constitutionally deficient and practically untenable, some courts require arrestees to also establish that they suffered an injury as a result of the Fourth Amendment violation. In addition, some courts have determined that a de minimis injury is insufficient to state a cause of action for excessive force under the Fourth Amendment. Because an analysis of the amount of injury an arrestee sustained lacks both a constitutional and pragmatic foundation, courts have developed a confusing patchwork of unconstitutional tests and considerations. As domestic police forces increase their use of nonlethal weapons, the courts' focus on the arrestee's injury and recognition of a de minimis injury exception to Fourth Amendment excessive-force claims linger as unconstitutional anachronisms. They fail to consider not only the Supreme Court's excessive-force jurisprudence, but also the deceptively minimal harm caused by current and future nonlethal weapons.

This Article has two primary parts. Part II begins with a discussion of the advent and use of the de minimis injury exception to Fourth Amendment excessive-force claims. Inseparably intertwined with the exception is some courts' requirement that an arrestee who alleges excessive force must also have suffered an injury. Thus, Part II continues by exploring how the circuits analyze Fourth Amendment excessive-force claims in relation to their requiring that a claimant allege an injury. The discussion highlights not only the lack of constitutional support for an injury requirement and a de minimis injury exception, but also the jurisprudential disorder created by these facets of the analysis. Part III discusses nonlethal weapons. It spotlights the physiological, psychological, and intersubjectively reliable experiences suffered by victims of current and future nonlethal weapons. Part III concludes by discussing why, in light of new nonlethal-weapon technology, a de minimis injury exception to Fourth Amendment excessive-force claims is impractical and should be abandoned.

1. Graham v. Connor, 490 U.S. 386, 396 (1989). 


\section{THE DE MINIMIS INJURY EXCEPTION TO FOURTH AMENDMENT EXCESSIVE-FORCE CLAIMS MUST BE ABANDONED BECAUSE IT LACKS A CONSTITUTIONAL BASIS}

\section{A. Introduction to Excessive-Force Claims}

In 42 U.S.C. $\S 1983$, federal law provides a remedy for excessiveforce claims based on the deprivation of a victim's constitutional rights. ${ }^{2}$ While all excessive-force analyses contemplate similar interests, the examination of constitutional excessive-force claims is not a monolithic inquiry, applicable across the spectrum of circumstances. As a result, when addressing an excessive-force claim under $\S 1983$, a court must begin its analysis "by identifying the specific constitutional right allegedly infringed by the challenged application of force.”3 Three different constitutional protections may apply. ${ }^{4}$ Courts choose the applicable protection based on an analysis of whether the alleged victim is "an arrestee, a pretrial detainee, or a convicted inmate of a penal institution." 5 Since 1985, the Fourth Amendment has governed excessive-force allegations made in the context of an arrest. ${ }^{6}$ Excessiveforce claims by pretrial detainees who are in state custody are subject to the Fourteenth Amendment substantive due process analysis. ${ }^{7}$ Convicted criminals' excessive-force claims are examined under the Eighth Amendment's proscription against cruel and unusual punishment. ${ }^{8}$

While this Article discusses Fourth Amendment excessive-force claims, a cursory understanding of the tests courts use to analyze claims under the Eighth and Fourteenth Amendments is beneficial. ${ }^{9}$ To

2. See, e.g., Estate of Smith v. Marasco, 318 F.3d 497, 505 (3d Cir. 2003) (citing Kneipp v. Tedder, 95 F.3d 1199, 1204 (3d Cir. 1996)).

3. Graham, 490 U.S. at 394 (citing Baker v. McCollan, 443 U.S. 137, 140 (1979)).

4. See id. at $395 \mathrm{n} .10$ (citing Bell v. Wolfish, 441 U.S. 520, 520-39 (1979); quoting Whitley v. Albers, 475 U.S. 312, 327 (1980)); Kinney v. Ind. Youth Ctr., 950 F.2d 462, 465 (7th Cir. 1991) (citing Graham, 490 U.S. at 394, 395 n.10, 397); Titran v. Ackman, 893 F.2d 145, 147-48 (7th Cir. 1990).

5. Andrews v. Neer, 253 F.3d 1052, 1060 (8th Cir. 2001); see Graham, 490 U.S. at 395 n.10 (citing Wolfish, 441 U.S. at 535-39; quoting Whitley, 475 U.S. at 327).

6. Palmer v. Sanderson, 9 F.3d 1433, 1436 (9th Cir. 1993) (citing Tennessee v. Garner, 471 U.S. 1, 8 (1985)).

7. See Graham, 490 U.S. at 392-95, 395 n.10 (citing Wolfish, 441 U.S. at 535-39).

8. Id. at 395 n.10 (citing Whitley, 475 U.S. at 327).

9. Cf. Flores v. City of Palacios, 381 F.3d 391, 401 (5th Cir. 2004) (emphasizing that “'cases 
establish an excessive-force claim under the Eighth Amendment, a prisoner must demonstrate that the force was "sadistically and maliciously applied for the very purpose of causing harm."10 Notably, an analysis of excessive-force claims under the Eighth Amendment differs from an analysis under the Fourth Amendment because Eighth Amendment jurisprudence contemplates the physical punishment of convicted prisoners and the intent to cause harm. ${ }^{11}$ In contrast, Fourth Amendment jurisprudence contemplates the right to be free from unreasonable, forcible seizure that restrains a citizen's liberty. ${ }^{12}$

The applicable test for pretrial detainees' Fourteenth Amendment excessive-force claims, however, is less clear. For example, the Fourth Circuit has determined that the analysis of Fourteenth Amendment excessive-force claims is no different than the aforementioned analysis of Eighth Amendment claims. ${ }^{13}$ In contrast, the Sixth and Seventh Circuits have indicated that analysis under the Fourteenth Amendment's Due Process Clause may grant pretrial detainees more protection than the Eighth Amendment. ${ }^{14}$ The Seventh Circuit, for example, reasoned that pretrial detainees who have not been found guilty of any crime "may not be 'punished' by the state in any way." 15 As a result, pretrial detainees in the Seventh Circuit must prove that a police officer "acted deliberately or with callous indifference, evidenced by an actual intent to violate [the plaintiff's] rights or reckless disregard for his rights."

arising under one amendment have consistently affected the parameters of rights that, while arising under different constitutional amendments, implicate similar policy concerns'” (quoting Petta v. Rivera, 143 F.3d 895, 914 n.31 (5th Cir. 1998))).

10. Johnson v. Breeden, 280 F.3d 1308, 1321 (11th Cir. 2002).

11. See Hudson v. McMillian, 503 U.S. 1, 5-7 (1992); Graham, 490 U.S. at 392-94.

12. See Valencia v. Wiggins, 981 F.2d 1440, 1444 (5th Cir. 1993) (citing Wilkins v. May, 872 F.2d 190, 192-93 (7th Cir. 1989)). See also Graham, 490 U.S. at 395 n.10.

13. See Orem v. Rephann, 523 F.3d 442, 446-48 (4th Cir. 2008).

14. See Griffin v. Hardrick, 604 F.3d 949, 953 (6th Cir. 2010) (citing Lewis v. Downey, 581 F.3d 467, 475 (7th Cir. 2009)).

15. Wilson v. Williams, 83 F.3d 870, 875 (7th Cir. 1996) (quoting Bell v. Wolfish, 441 U.S. 520, 535 (1979)).

16. Anderson v. Gutschenritter, 836 F.2d 346, 349 (7th Cir. 1988) (citing Shelby Cty. Jail Inmates v. Westlake, 798 F.2d 1085, 1094 (7th Cir. 1986)). 
B. The History of De Minimis Injury in the Context of Fourth Amendment Excessive-Force Claims

1. Graham: The Fourth Amendment Is Applicable to Excessive-Force Claims Arising Within the Context of an Arrest

Before 1989, several circuits recognized that the Fourth Amendment governed an arrestee's excessive-force claim, ${ }^{17}$ while other circuits analyzed all excessive-force claims within the context of substantive due process. $^{18}$ In Graham v. Connor, the Supreme Court validated the former principle when it held that the Fourth Amendment "governs a free citizen's claim that law enforcement officials used excessive force in the course of making an arrest." 19 In Graham, the Court determined that a Fourth Amendment excessive-force analysis was one of "objective reasonableness." 20 As the Court articulated, the analysis focuses on the police officer's actions and whether those actions were "'objectively reasonable' in light of the facts and circumstances confronting [the officer], without regard to [the officer's] underlying intent or motivation." 21 As a police officer's "right to make an arrest or investigatory stop necessarily carries with it the right to use some degree of physical coercion,"22 the analysis requires a balancing of "the nature and quality of the intrusion on the individual's Fourth Amendment interests against the countervailing governmental interests at stake.,23 The factors courts must consider include "the severity of the crime at issue, whether the suspect poses an immediate threat to the safety of the officers or others, and whether he is actively resisting arrest or attempting to evade arrest by flight." 24

17. See Palmer v. Sanderson, 9 F.3d 1433, 1436 (9th Cir. 1993) (finding that "the Fourth Amendment governs not only whether a person or thing is subject to a 'seizure,' but also 'the manner in which a ... seizure is conducted.” (quoting Tennessee v. Garner, 471 U.S. 1, 7-8 (1984))) See also Lester v. City of Chicago, 830 F.2d 706, 710 (7th Cir. 1987); Robins v. Harum, 773 F.2d 1004, 1010 (9th Cir. 1985).

18. See Graham v. Connor, 490 U.S. 386, 393 (1989) (finding that most lower federal courts applied a substantive due process test to excessive force claims).

19. Id. at 388 .

20. Id.

21. Id. at 397 (citing Scott v. United States, 436 U.S. 128, 137-39 (1978); Terry v. Ohio, 392 U.S. 1, 21 (1968)).

22. Id. at 396 (citing Terry, 392 U.S. at 22-27).

23. Id. (quoting Garner, 471 U.S. at 8) (internal quotation marks omitted).

24. Id. (citing Garner, 471 U.S. at 8-9). 
Notably, in articulating the analytical framework for an analysis of Fourth Amendment excessive-force claims, the Court did not examine the magnitude of the arrestee's injury. Indeed, the very test the district court and Fourth Circuit adopted in Graham v. City of Charlotte-which the Court rejected-included, among other things, an examination of the "extent of the injury inflicted" upon the arrestee. ${ }^{25}$ Instead, the Court's analysis focused on the police officer's actions, the "reasonableness" of the particular force employed, and the objective reasonableness of the type of force under the circumstances. ${ }^{26}$ To be sure, "its opinion... contains no quantum-of-injury criterion." ${ }^{27}$ Paradoxically, one of the Court's axioms often cited in support of a de minimis injury exception"“[n]ot every push or shove, even if it may later seem unnecessary in the peace of a judge's chambers violates the Fourth Amendment",28_ focused on the amount of force, not on the arrestee's injury.

\section{The Genesis of De Minimis Injury Lexicon Within the Context of} Fourth Amendment Excessive-Force Claims

The phrase "de minimis injury" first appeared within the context of a Fourth Amendment excessive-force claim in the Eastern District of Pennsylvania, three months before the Supreme Court issued its Graham decision. ${ }^{29}$ In Iafrate v. Globosits, the plaintiff alleged that his arresting officer used excessive force in violation of his federal constitutional rights. $^{30}$ While arresting the plaintiff for violating the local loitering ordinance, the officer allegedly shoved the plaintiff into the police cruiser's door several times and tried to knee the plaintiff in the groin. ${ }^{31}$

25. Id. at 390 (quoting 644 F. Supp. 246, 248 (W.D.N.C. 1986), vacated sub nom., Graham, 490 U.S. 386).

26. Id. at 395-97.

27. Johnson v. Morel, 876 F.2d 477, 481 (5th Cir. 1989) (en banc) (Rubin, J., concurring in part), abrogated by Harper v. Harris Cnty., 21 F.3d 597 (5th Cir. 1994) (per curiam).

28. E.g., Washpon v. Parr, 561 F. Supp. 2d 394, 407 n.40 (S.D.N.Y. 2008) (quoting Graham, 490 U.S. at 396). The Washpon court further found that a "[d]e minimis injury can serve as conclusive evidence that de minimis force was used.”' Id. (quoting Carr v. Deeds, 453 F.3d 593, 606 (4th Cir. 2006)). 989).

29. Iafrate v. Globosits, Civ. A. No. 87-5612, 1989 WL 14062, at *4 n.3 (E.D. Pa. Feb. 22,

30. See id. at $* 1$. Although the court does not characterize it as such because the alleged excessive-force claim arose out of an arrest, the implication is that the plaintiff alleged excessive force in violation of the Fourth Amendment. Id.

31. Id. at $* 2$. 
The plaintiff and the police officer ultimately scuffled on the ground, after which the plaintiff was placed into custody. ${ }^{32}$ The plaintiff suffered a cut to his hand, which was subsequently cleaned and bandaged. ${ }^{33}$

The court began its discussion of the plaintiff's excessive-force allegation by recognizing that "[t]he use of force to effect a lawful arrest is privileged." ${ }^{34}$ To succeed, the plaintiff must demonstrate that "the officer lacked probable cause ... or that the force used was excessive.”35 In its analysis of the plaintiff's excessive-force claim, the court focused on what it thought was the insignificant nature of the plaintiff's injury. ${ }^{36}$ It noted that "the only possible injury [the] plaintiff could have suffered before he began resisting was a cut to his finger, which ... required no medical attention." ${ }^{37}$ Indeed, although the plaintiff also alleged that the arresting officer's use of force aggravated his preexisting back problems, ${ }^{38}$ the court did not find that the plaintiff "provided anything more than a scintilla of evidence to support a claim of excessive force."39 In characterizing the arresting officer's alleged use of force as "selfdefense," the court noted that the plaintiff would have suffered nothing more than de minimis injuries from blows that did not strike their intended target. $^{40}$

Following the Iafrate court's use of “de minimis injury,” the phrase appeared again, a year later, in Judge Goldberg's dissenting opinion in Wisniewski v. Kennard. ${ }^{41}$ Here, the plaintiff, a prisoner, escaped from jail and was later apprehended. ${ }^{42}$ The plaintiff alleged that the arresting officer violated the Fourth Amendment when he used excessive force while apprehending him. ${ }^{43}$ The plaintiff alleged that the arresting officer "handcuffed [the plaintiff], then placed his revolver in [the plaintiff's] mouth, threatened to blow his head off, and twice punched him in the

32. Id.

33. Id.

34. Id. at *3 (citing Edwards v. City of Philadelphia, 860 F.2d 568, 570 (3d Cir. 1988); McKinney v. Whitfield, 736 F.2d 766, 769 (D.C. Cir. 1984)).

35. Id. at *3 (citing Edwards, 860 F.2d at 571, 572; Belcher v. United States, 511 F. Supp. 476, 484 (E.D. Pa. 1981); Kedra v. City of Philadelphia, 454 F. Supp. 652, $672-73$ (E.D. Pa. 1978)).

36. Id. at $* 4$

37. Id. (footnote omitted).

38. Id. at $* 4 \mathrm{n} .2$.

39. Id. at *4.

40. Id. at $* 4$ n. 3 .

41. 901 F.2d 1276, 1279 (5th Cir. 1990) (Goldberg, J., dissenting).

42. Id. at 1277 (per curiam).

43. Id. 
stomach."44 The plaintiff further alleged that the officer's actions frightened him, caused him mental anguish, and caused him to suffer bad dreams. ${ }^{45}$ The district court granted summary judgment in favor of the arresting officer, and the Fifth Circuit affirmed the decision. ${ }^{46}$ The majority's short opinion relied on its earlier decision in Johnson $v$. Morel. ${ }^{47}$ As understood by the Wisniewski court, Morel required that a plaintiff demonstrate "proof of a significant injury as a threshold for the recovery of money damages under 42 U.S.C. § 1983 where excessive force in an illegal arrest was claimed." ${ }^{48}$ Although the Wisniewski court recognized that the Morel court had not addressed the question of whether a non-physical injury could constitute a significant injury, the court nevertheless determined that the "[plaintiff's] injuries [we]re not significant within the meaning of Morel." $"$

In his dissent, Judge Goldberg disagreed with the majority's opinion that the officer was entitled to summary judgment. ${ }^{50}$ Instead, Judge Goldberg believed that the plaintiff had suffered a significant injury pursuant to Morel. ${ }^{51}$ Judge Goldberg noted with approval, however, that the Morel court characterized injuries that do not meet the "significant"” standard as "minor harms and transient distress[es]." 52 Indeed, Judge Goldberg recognized that pursuant to Morel, those sorts of insignificant "de minimis injuries" do not give rise to a constitutional claim of excessive force. ${ }^{53}$ Judge Goldberg's use of "de minimis injury" is the first time the phrase enters the lexicon of Fourth Amendment excessiveforce jurisprudence at the circuit level.

44. Id.

45. Id.; id. at 1278 (Goldberg, J., dissenting).

46. Id. at 1277 (per curiam).

47. Id. (citing Johnson v. Morel, 876 F.2d 477, 480 (5th Cir. 1989) (en banc) (per curiam), abrogated by Harper v. Harris Cnty., 21 F.3d 597 (5th Cir. 1994) (per curiam)).

48. Id. (emphasis added) (citing Morel, 876 F.2d at 480).

49. Id.

50. Id. (Goldberg, J., dissenting).

51. Id.

52. Id. at 1279 (quoting Morel, 876 F.2d at 480).

53. Id. 
3. The Supreme Court's Rejection of a Mandatory Quantum of Injury for Eighth Amendment Excessive-Force Claims

In McMillian v. Hudson, the Supreme Court questioned the "significant injury" prong of excessive-force analysis ${ }^{54}$ - upon which Judge Goldberg relied to implant an explicit de minimis exception into Fourth Amendment jurisprudence-and subsequent decisions recognized the invalidity of the requirement. ${ }^{55}$ In Hudson, an inmate filed an Eighth Amendment claim alleging that prison guards used excessive force after a verbal confrontation with the inmate. ${ }^{56}$ The inmate alleged that after the verbal exchange, one guard held him in place while kicking and punching him as another guard punched him in the mouth, eyes, chest, and stomach. ${ }^{57}$ As a result of the confrontation, the inmate suffered "minor bruises and swelling of his face, mouth, and lip," loosened teeth, and a cracked dental plate. ${ }^{58}$ While the district court found that the prison guards used excessive force, the Fifth Circuit reversed. ${ }^{59}$

The Fifth Circuit articulated a test for Eighth Amendment excessiveforce claims, which required that inmates must demonstrate, among other things, that the injury resulting from the force was "significant.",60 After characterizing the inmate's injuries as "minor" and noting that he did not require medical attention, the Fifth Circuit ruled in favor of the prison guards. ${ }^{61}$ The Supreme Court, however, reversed the Fifth Circuit and held that there is no "significant injury" requirement for valid Eighth Amendment excessive-force claims. ${ }^{62}$

The Court began by reexamining precedent regarding violations of the Eighth Amendment's prohibition against cruel and unusual

54. 503 U.S. 1, 9 (1991).

55. Knight v. Caldwell, 970 F.2d 1430, 1432 (5th Cir. 1992) (recognizing that Hudson overturned Fifth Circuit law requiring significant injury for excessive-force claims). In recognizing the Supreme Court's rejection of a "significant injury" requirement for Eighth Amendment excessive-force claims, the Fifth Circuit held that the "significant injury" standard no longer governed Fourth Amendment excessive-force claims. Harper v. Harris Cnty., 21 F.3d 597, 600 (5th Cir. 1994) (per curiam) (citing Hudson, 503 U.S. 1).

56. Hudson, 503 U.S. at 4.

57. Id.

58. $I d$.

59. Id. at 4-5 (citing 929 F.2d 1014 (5th Cir. 1990) (per curiam)).

60. Id. at 5 (citing 929 F.2d at 1015).

61. Id.

62. Id. at 4,12 . 
punishment during a prison riot. ${ }^{63}$ It reaffirmed that the inquiry under the Eighth Amendment rests on whether the "force was applied in a goodfaith effort to maintain or restore discipline, or maliciously and sadistically to cause harm." ${ }^{4}$ The Court affirmed that in balancing the need for order and discipline against the risk of injury, “"[p]rison administrators ... should be accorded wide-ranging deference in the adoption and execution of policies and practices that in their judgment are needed to preserve internal order and discipline and to maintain institutional security.",65 Because the interests that existed in its previous Eighth Amendment analysis regarding cruel and unusual punishment were similar to Eighth Amendment excessive-force claims, the Court held that the same inquiry applied. ${ }^{66}$

The Court rejected the notion that a claimant must suffer a requisite measure of injury to support an Eighth Amendment claim. ${ }^{67}$ It noted that when prison officials intentionally use force to cause harm, "contemporary standards of decency always are violated ... whether or not significant injury is evident." 68 Indeed, some types of force that, theoretically, leave little or no injury would nonetheless be excessive under certain circumstances. To that end, the Court reasoned that if the inquiry rested on some capricious measure of injury, "any physical punishment, no matter how diabolic or inhuman," would be permissible so long as it inflicted less than the proscribed amount of harm on the victim. ${ }^{69}$ The Court, however, did not preclude an inquiry into the victim's injury. ${ }^{70}$ Instead, the Court held that the extent of the injury is one factor among several that may suggest the use of force was excessive. $^{71}$ The Court also discussed the relevance of the nature of force prison officials employ. ${ }^{72}$ It reaffirmed the maxim that not "every malevolent touch by a prison guard" will rise to the level of an Eighth

\footnotetext{
63. Id. at $5-7$.

64. Id. at 7.

65. Id. at 6 (alteration in original) (quoting Whitley v. Albers, 475 U.S. 312, 321-22 (1986)).

66. Id. at 6-7.

67. Id. at $8-9$.

68. Id. at 9 (citing Whitley, 475 U.S. at 327).

69. Id.

70. See id. at 7 (citing Whitley, 475 U.S. at 321).

71. Id. Other factors include the "need for application of force, the relationship between that need and the amount of force used, the threat 'reasonably perceived by the responsible officials,' and 'any efforts made to temper the severity of a forceful response."' Id. (quoting Whitley, 475 U.S. at

72. See id. at $8-10$.
} 321). 
Amendment violation. ${ }^{73}$ As such, de minimis uses of force will not violate the Eighth Amendment so long as they are not " "repugnant to the conscience of mankind." 74

4. Despite Graham and Hudson, a Review of the Magnitude of an Arrestee's Injury Continues

The phrase de minimis injury appeared within the context of excessive-force claims analyzed under the Eighth and Fourteenth Amendments at various times in the five years after Wisniewski and the three years after Hudson. ${ }^{75}$ The Fourth Circuit, however, next entertained the concept that de minimis injuries do not provide a basis for excessive-force claims under the Fourth Amendment. ${ }^{76}$ Initially, in Browning v. Snead, the district court faced an argument by a defendant police officer and a municipality that a plaintiff's excessive-force claim should be dismissed because the plaintiff had presented evidence of no more than a de minimis injury. ${ }^{77}$ The court implied that evidence of de minimis injuries in a case alleging excessive force may not suffice to show a constitutional violation under the Fourth Amendment. ${ }^{78}$ The court refused, however, to address the validity of the defendant's de minimis injury argument. ${ }^{79}$ Instead, the court found that "[e]ven if the de minimis [injury] standard applies to Fourth Amendment claims," the plaintiff's allegation that he suffered a detached retina was serious enough to deny the defendants' motion to dismiss. ${ }^{80}$

A year later, and four years after Hudson, the Fourth Circuit recognized a de minimis injury exception to Fourth Amendment excessive-force claims. ${ }^{81}$ In Ritchie $v$. Jackson, a plaintiff alleged that a police officer used excessive force when "one officer grabbed [the plaintiff] by the shirt[,] lifted him off the ground[,] and [applied]

\footnotetext{
73. Id. at 9 (citing Johnson v. Glick, 481 F.2d 1028, 1033 (2d Cir. 1973)).

74. Id. at 9-10 (quoting Whitley, 475 U.S. at 327).

75. See, e.g., Norman v. Taylor, 25 F.3d 1259, 1263 (4th Cir. 1994) (en banc), abrogated by Wilkins v. Gaddy, 130 S. Ct. 1175 (2010).

76. Browning v. Snead, 886 F. Supp. 547, 552 (S.D. W. Va. 1995).

77. See id.

78. Id.

79. Id.

80. Id.

81. Ritchie v. Jackson, No. 95-3057, 1996 WL 585152, at *2 (4th Cir. Oct. 11, 1996) (per curiam).
} 
handcuffs too tightly." ${ }^{2}$ The court held the plaintiff "allege[d] no more than [a] de minimis injury" and, as a result, the "claims of excessive force [were] without merit," ${ }^{\text {"3 }}$ thereby linking the extent of the plaintiff's injury with the validity of the claim. In recognizing this relationship between allegations of de minimis injuries and their inability to constitute meritorious excessive-force claims, the Ritchie court cited the Eighth Circuit's holding in Foster v. Metropolitan Airports Commission, a preHudson case. $^{84}$ Foster demonstrates that the Eighth Circuit, in evaluating the validity of excessive-force claims, looked for allegations of "long-term injury" 85 and "permanent injury" inquiry the Supreme Court forbade in Hudson. ${ }^{87}$ The severity of injury that the Eighth Circuit required in Foster - and upon which the Fourth Circuit based the de minimis injury exception-was therefore similar in scope to the extent of the injury that the Fifth Circuit required in Morel ${ }^{88}$ and that Hudson had rejected. ${ }^{89}$ Ritchie's citation to Foster and its focus on an arbitrary quantity of injury, however, solidified a de minimis injury exception to excessive-force claims in Fourth Amendment jurisprudence.

Since the Supreme Court rejected the "significant injury" requirement under the Eighth Amendment, courts have widely recognized that a Fourth Amendment excessive-force victim need not demonstrate a "significant" injury. ${ }^{90}$ While the Graham Court, however, made no mention of the need for an injury in a Fourth Amendment excessive-force claim, some circuits still require an arbitrary amount of injury. By requiring an injury, those circuits have perpetuated the de

82. Id.

83. Id. (citing Foster v. Metro. Airports Comm’n, 914 F.2d 1076, 1082 (8th Cir. 1990)).

84. Id. (citing Foster, 914 F.2d at 1082).

85. Foster, 914 F.2d at 1082 (citing Hannula v. City of Lakewood, 907 F.2d 129, 132 n.3 (10th Cir. 1990)).

86. Id.

87. See supra Part II.B.3.

88. Compare Johnson v. Morel, 876 F.2d 477, 480 (5th Cir. 1989) (en banc) (per curiam) (requiring “significant injury”), abrogated by Harper v. Harris Cnty., 21 F.3d 597 (5th Cir. 1997) (per curiam), with Foster, 914 F.2d at 1082 (noting the absence of both "long-term injury" and “permanent injury”).

89. See supra note 55 and accompanying text.

90. E.g., Bastien v. Goddard, 279 F.3d 10, 14 (1st Cir. 2002) (““[A] trialworthy "excessive force” claim is not precluded merely because only minor injuries were inflicted by the seizure.' That view is widely held.” (alteration in original) (citations and footnote omitted) (quoting Alexis v. McDonald's Rests. of Mass., Inc., 67 F.3d 341, 353 (1st Cir. 1995))); Harper, 21 F.3d at 600 (per curiam) (holding that the "significant injury" standard was no longer valid in Fourth Amendment excessive-force claims) (citing Knight v. Caldwell, 970 F.2d 1430, 1432 (5th Cir. 1992)). 
minimis injury exception, thus precluding what might otherwise be valid claims. Left to their own devices by the Supreme Court's silence on the issue, courts have developed a hodgepodge of tests and considerations to cope with this unconstitutional requirement.

\section{The De Minimis Injury Exception Now}

Whether an arrestee must establish an injury in a Fourth Amendment excessive-force claim has been answered differently in almost every circuit. Courts, however, generally fall into one of three categories regarding an injury requirement and the recognition of the de minimis injury exception. First, there are those circuits that require an arrestee to establish an injury and, if the injury is de minimis, the arrestee fails to state a cause of action. ${ }^{91}$ Next, there are those circuits in which the circuit court generally follows the Graham analysis, but the circuit itself or district courts nevertheless recognize an injury requirement or injurybased consideration. ${ }^{92}$ Finally, some circuits strictly follow the Graham analysis and neither require an injury nor recognize a de minimis injury exception. $^{93}$

The Supreme Court has added another layer to the analysis. While not addressing the Fourth Amendment, the Court recently revisited Hudson. It directly addressed the de minimis injury exception within the context of the Eighth Amendment and found it wanting. ${ }^{94}$

1. Circuit Courts that Require an Injury and Have Recognized the De Minimis Injury Exception

\section{a. The Fifth Circuit}

Of the circuits that require an injury to succeed in a Fourth Amendment excessive-force claim, the Fifth Circuit's test garners the most use and attention. After the Supreme Court's decision in Graham, but before the Court's decision in Hudson, the Fifth Circuit articulated a three-prong test for an excessive-force claim under the Fourth

\footnotetext{
91. See infra Part II.C.1.

92. See infra Part II.C.2.

93. See infra Part II.C.3.

94. See infra Part II.C.4.
} 
Amendment. In Morel, the Fifth Circuit stated that an arrestee must establish "(1) a significant injury, which (2) resulted directly and only from the use of force that was clearly excessive to the need; and the excessiveness of which was (3) objectively unreasonable."95 While the Fifth Circuit submitted that it was guided by the Supreme Court's decision in Graham, ${ }^{96}$ the Graham analysis did not require an injury and rejected the opportunity to adopt such a requirement. ${ }^{97}$ Indeed, the Morel court failed to cite any authority from Graham to support the requirement. ${ }^{98}$ Nevertheless, the "significant injury" requirement lived on in Fifth Circuit jurisprudence for approximately three years until Hudson. $^{99}$ After the Supreme Court rejected a significant-injury requirement for Eighth Amendment claims in Hudson, the Fifth Circuit amended its Fourth Amendment three-prong test. ${ }^{100}$ It did not jettison the focus on an injury and refocus on the force used, which would have thus brought it more in line with the original Graham decision. Instead, it simply dropped the word "significant" from the test to reduce the quantum of injury required while still requiring "some form of injury.",101 As evidence of the Fifth Circuit's reluctance to change its analysis, save the removal of the word "significant," the test remained the same.

While the Fifth Circuit's "more than de minimis injury” requirement is untenable within the context of Supreme Court Fourth Amendment jurisprudence, it is no more tenable as applied in practice. In trying to articulate an understandable and workable analysis of what constitutes more than a de minimis injury, the court engaged in a convoluted analysis. Graham compels courts to decide Fourth Amendment excessive-force claims based on whether the force was objectively reasonable under the circumstances. ${ }^{102}$ In attempting to describe how its injury requirement factors into an excessive-force claim, the Fifth Circuit

\footnotetext{
95. Johnson v. Morel, 876 F.2d 477, 480 (5th Cir. 1989) (en banc) (per curiam), abrogated by Harper v. Harris Cnty., 21 F.3d 597 (5th Cir. 1994) (per curiam) (footnote omitted).

96. Id. at 478 .

97. See supra notes $26-28$ and accompanying text.

98. Morel, 876 F.2d at 480; id. at 481 (Rubin, J., concurring in part) (criticizing the majority for adding significant-injury and causation requirements to the analysis in Graham).

99. Hudson v. McMillian, 503 U.S. 1, 4 (1992) (rejecting significant injury requirements).

100. Knight v. Caldwell, 970 F.2d 1430, 1432 (5th Cir. 1992).

101. Williams v. Bramer, 180 F.3d 699, 703-04 (quoting Jackson v. Culbertson, 984 F.2d 699, 700 (5th Cir. 1993) (per curiam)), decision clarified on reh'g by 186 F.3d 633 (5th Cir. 1999) (per curiam).

102. Graham v. Connor, 490 U.S. 386, 396-97 (1989).
} 
instructs that " "[t]he amount of injury necessary to satisfy our requirement of "some injury" and establish a constitutional violation is directly related to the amount of force that is constitutionally permissible under the circumstances.", 103 To know what is constitutionally permissible in any particular circumstance, however, the analysis comes full circle and must examine, pursuant to Graham, whether the force was objectively reasonable under the circumstances. Therefore, the Court's analytical structure to determine what constitutes a de minimis injury is a useless exercise that brings one back to the original Graham inquiry. Further, despite the Supreme Court's admonishment in Hudson that requiring arbitrary amounts of injury conflicts with excessive-force jurisprudence, the Fifth Circuit recognized that whether an injury is de minimis is "subjective-it is defined entirely by the context in which the injury arises."104

In addition to this convoluted analysis, the Fifth Circuit has virtually relented on the injury requirement without truly letting go. In Flores v. City of Palacios, a plaintiff alleged purely psychological injuries within the context of a Fourth Amendment excessive-force claim. ${ }^{105}$ The Fifth Circuit recognized that under certain circumstances where a plaintiff lacks a physical injury, psychological injuries could nonetheless fulfill the "injury" requirement. ${ }^{106}$ Although the court recognized that a plaintiff need not allege a physical injury, it reintroduced a significantinjury requirement under a new name-the "substantial injury" requirement within the context of psychological injuries. ${ }^{107}$ Consequently, where plaintiffs have no physical injury as a result of excessive force used against them-as is regularly the case with nonlethal weapons ${ }^{108}$ - they must demonstrate not only some arbitrary quantum of psychological injury, but, seemingly in conflict with the Hudson Court's intent, it must also be "substantial.",109

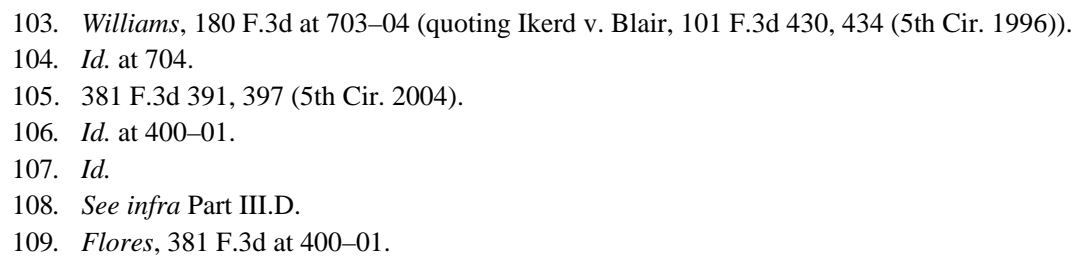




\section{b. The Tenth Circuit}

The Fifth Circuit is not alone in its "more than a de minimis injury" requirement for a plaintiff to succeed on a Fourth Amendment excessiveforce claim. Nor is it alone in the puzzling and, at times, difficult-toreconcile consequences of recognizing a de minimis injury exception to Fourth Amendment excessive-force claims. For example, while the Tenth Circuit has "decline[d] to adopt a 'bright-line' standard dictating that force cannot be 'excessive' unless it leaves visible cuts, bruises, abrasions[,] or scars," 110 it has recognized that a plaintiff must demonstrate "some actual injury caused by the unreasonable seizure that is not de minimis, be it physical or emotional." "111 These two statements seem to be mutually exclusive and, indeed, were difficult enough for a district court judge to reconcile that the Tenth Circuit was forced to reaffirm - without abandoning its de minimis injury exception- "that an excessive force claim is not dependent on physical injury or even physical contact, but on 'patently unreasonable conduct' by the arresting officer."112 Presumably the Tenth Circuit, therefore, has left its district courts wondering why they should investigate the magnitude of the injury if an excessive-force claim does not turn on the scale of the injury.

\section{c. The Eighth Circuit}

The Eighth Circuit's handling of the de minimis injury exception in Fourth Amendment jurisprudence is similarly difficult to reconcile. In 2005, the Eighth Circuit stated in unequivocal terms that "[a]n 'actual injury' must be shown to support an excessive force claim under the Fourth Amendment."113 As recently as 2009, however, the court reaffirmed a hedging of the relevancy of an injury's severity in Fourth Amendment excessive-force claims. In Cook v. City of Bella Villa, the Eighth Circuit in one breath reaffirmed a previous noncommittal determination that "“[i]t remains an open question in [the Eighth Circuit]

110. Holland ex rel. Overdorff v. Harrington, 268 F.3d 1179, 1195 (10th Cir. 2001).

111. Cortez v. McCauley, 478 F.3d 1108, 1129 n.25 (10th Cir. 2007) (en banc) (citing Tarver v. City of Edna, 410 F.3d 745, 752 (5th Cir. 2005)).

112. Grass v. Johnson, 322 F. App’x. 586, 590 (10th Cir. 2009) (quoting Cortez, 478 F.3d at 1131).

113. Hanig v. Lee, 415 F.3d 822, 824 (8th Cir. 2005) (quoting Dawkins v. Graham, 50 F.3d 532, 535 (8th Cir. 1995)). 
whether an excessive force claim requires some minimum level of injury," "114 while at the same time stating that the "lack, or minor degree, of any injury sustained during an arrest is relevant in considering the reasonableness of the force used." 115 In support of the latter, the court cited to cases that recognized "a de minimis amount of force, without any resulting injury, [is] insufficient to support a finding of a constitutional violation."116 Put another way, while the court stated that it had not determined whether a Fourth Amendment excessive-force claim requires some arbitrary, minimum level of injury, it nonetheless contradictorily cited with approval the premise that some level of more than de minimis injury is required. Indeed, although the Eighth Circuit attempts to distance itself from the implications associated with fully embracing the requirement that an arrestee demonstrate some quantum of injury, its jurisprudence is replete with decisions that affirm the theory that " $d e$ minimis injuries ... preclude a claim for excessive force."117

In addition, the Eighth Circuit has repeatedly reaffirmed the postGraham, pre-Hudson need for a permanent injury to survive a Fourth Amendment excessive-force claim in some situations. In 1990, the Eighth Circuit, in evaluating the validity of an excessive-force claim where handcuffs were applied too tightly, required allegations of "longterm injury"118 and "permanent injury." "119 In Crumley, eleven years after Hudson, the Eighth Circuit reaffirmed its pre-Hudson requirement that where a Fourth Amendment excessive-force claim arises out of the manner in which handcuffs are applied, an arrestee must allege "longterm or permanent physical injury." "120 In so holding, the Eighth Circuit reaffirmed its raising of the evidentiary bar for certain Fourth Amendment excessive-force claims. It did so by not only requiring more than de minimis injury or more than a minor injury, but, indeed,

114. 582 F.3d 840, 850 (8th Cir. 2009) (quoting Hunter v. Namanny, 219 F.3d 825, 831 (8th Cir. 2000)).

115. Id. at 851 (citing Greiner v. City of Champlin, 27 F.3d 1346, 1354 (8th Cir. 1994)).

116. Id. (citing Crumley v. City of St. Paul, 324 F.3d 1003, 1007 (8th Cir. 2003); Foster v. Metro. Airports Comm'n, 914 F.2d 1076, 1082 (8th Cir. 1990)).

117. E.g., Andrews v. Fuoss, 417 F.3d 813, 818 (8th Cir. 2005) (citing Crumley, 324 F.3d at 1007).

118. Foster, 914 F.2d at 1082 (citing Hannula v. City of Lakewood, 907 F.2d 129, 132 n.3 (10th Cir. 1990)); supra notes 83-84 and accompanying text.

119. Foster, 914 F.2d at 1082; supra notes 83-84 and accompanying text.

120. Crumley, 324 F.3d at 1008. 
something rising to the level of a severe or permanent injury. ${ }^{121}$ While Foster and Crumley dealt specifically with allegations that handcuffs were applied too tightly, the "permanent injury" analysis has bled into cases that did not consider the tightness of handcuffs, but instead the manner in which the arrestee was placed in handcuffs. For example, the Eighth Circuit has used a "less-than-permanent" injury to support a conclusion that the alleged scrapes, bruises, and aggravation of a prior shoulder injury incurred during the subduing and positioning of an arrestee in order to apply handcuffs did not support the conclusion that the police officer used excessive force. ${ }^{122}$

\section{d. The Fourth Circuit}

Although the Fourth Circuit has not fully developed a position regarding a de minimis injury exception, it has at least created uncertainty regarding its acknowledgment of a de minimis injury exception within the context of the Fourth Amendment and, at most, has recognized the exception. The concept of a de minimis injury exception entered the Fourth Circuit's jurisprudence by way of the Ritchie decision, in which the court held that a plaintiff's Fourth Amendment excessiveforce claim is meritless when he alleges "no more than [a] de minimis injury." have continued to use the exception and have relied on Ritchie ${ }^{124}$ or nowoverruled Eighth Amendment cases recognizing the de minimis injury exception. $^{125}$

121. Id.

122. Wertish v. Krueger, 433 F.3d 1062, 1067 (8th Cir. 2006).

123. Ritchie v. Jackson, No. 95-3057, 1996 WL 585152, at *2 (4th Cir. Oct. 11, 1996) (per curiam) (citing Foster, 914 F.2d at 1082); see supra notes 81-83 and accompanying text.

124. See, e.g., Lassiter v. Reece, No. 3:07-885-HFF-JRM, 2008 WL 2852164, at *5 (D.S.C. July 22, 2008), abrogated by Wilkins v. Gaddy, 130 S. Ct. 1175 (2010) (per curiam); Batts v. Lyle, No. 3:06-1875-TLW-JRM, 2007 WL 2220402, at*4 (D.S.C. July 27, 2007), abrogated by Wilkins, 130 S. Ct. 1175; Vanover v. Blendowski, No. 3:05-2956-DCN-JRM, 2006 WL 3513682, at *5 (D.S.C. Dec. 5, 2006), abrogated by Wilkins, 130 S. Ct. 1175; Wilkerson v. Hester, 114 F. Supp. 2d 446, 463 (W.D.N.C. 2000), abrogated by Wilkins, 130 S. Ct. 1175. The Ritchie case is spelled as "Richie" in some of the preceding cases.

125. See, e.g., Grier v. Cappo, No. 4:05-0426-TLW-TER, 2007 WL 858868, at *6 (D.S.C. Mar. 19, 2007) (citing Norman v. Taylor, 25 F.3d 1259, 1262 (4th Cir. 1994) (en banc), abrogated by Wilkins, 130 S. Ct. 1175 (per curiam)); Mickle v. Ahmed, 444 F. Supp. 2d 601, 619 (D.S.C. 2006) (discussing Norman, 25 F.3d 1259); Allmond v. Alexandria Sheriff's Dep't, No. Civ.A. 02-309-A, 2002 WL 32514956, at *3 (E.D. Va. June 4, 2002) (citing Riley v. Dorton, 115 F.3d 1159, 1164 (4th Cir. 1997) (en banc), abrogated by Wilkins, 130 S. Ct. 1175)); Martin v. Mendoza, 230 F. Supp. 2d 
The district courts' reliance on Ritchie and the now-defunct Eighth Amendment analysis is understandable based on the murky signals coming from the Fourth Circuit. For example, seven years after the Ritchie court recognized a de minimis injury exception, the Fourth Circuit had the opportunity to tangentially discuss the de minimis injury concept within the context of the Fourth Amendment in Jones $v$. Buchanan. ${ }^{126}$ In Jones, an arrestee brought an excessive-force claim against a police officer who allegedly knocked him to the floor, "jumped on him, crush[ed his] nose, lacerat[ed] his lips and nose, and bruis[ed] his ribs." 127 In analyzing the arrestee's allegation, ostensibly within the framework the Supreme Court provided in Graham, the Fourth Circuit methodically discussed four factors to consider when determining whether a plaintiff has alleged sufficient facts to rise to the level of a Fourth Amendment excessive-force claim. ${ }^{128}$ The first three factors, (1) the " "severity of the crime at issue,"” (2) "whether the 'suspect poses an immediate threat to the safety of the officers or others,"” and (3) "whether the suspect "is actively resisting arrest or attempting to evade arrest by flight,"” were followed by a citation to, and were direct quotations from, the Graham decision. ${ }^{129}$ The fourth factor, "the severity of [plaintiff's] injury," however, lacks a citation to Graham ${ }^{130}$ and was instead arguably supported by Supreme Court dicta ${ }^{131}$ and citations to Fourth Circuit cases, ${ }^{132}$ some of which validated the inquiry into the

665, 671-72 (D. Md. 2002) (citing Norman, 25 F.3d at 1263); White v. Md. Transp. Auth., 151 F. Supp. 2d 651, 657 (D. Md. 2001) (citing Riley, 115 F.3d at 1166-68). See also Lassiter, 2008 WL 2852164 at *5; Batts, 2007 WL 2220402 at *4; Vanover, 2006 WL 3513682 at *5; Wilkerson, 114 F. Supp. 2d at 463 . Each of these last four Eighth Amendment cases was overruled by Wilkins, $130 \mathrm{~S}$. Ct. 1175 (2010), discussed in Part II.C.4.

126. 325 F.3d 520, 530-31 (4th Cir. 2003).

127. Id. at $522-23$.

128. Id. at $527-31$.

129. Id. at 527 (quoting Graham v. Connor, 490 U.S. 386, 396 (1989)).

130. Id. at $527-28$.

131. Id. at 531 ("Our conclusion is confirmed by the uncontested fact that the force was not so excessive that respondent suffered hurt or injury." (quoting Saucier v. Katz, 533 U.S. 194, 209 (2001), overruled on other grounds by Pearson v. Callahan, 555 U.S. 223 (2009))). But see Morrison v. Bd. of Trs., 583 F.3d 394, 403 (6th Cir. 2009) (construing the Court's comments in Saucier about the magnitude of injury an arrestee sustained as a "passing reference as a mere expression of the Court's skepticism about the adequacy of [the alleged] injuries, without adopting a definitive stance on the issue").

132. Jones, 325 F.3d at 527 (citing Rowland v. Perry, 41 F.3d 167, 174 (4th Cir. 1994); Pressly v. Gregory, 831 F.2d 514, 517 (4th Cir. 1987)); id. at 530 (citing Kane v. Hargis, 987 F.2d 1005, 1008 (4th Cir. 1993) (per curiam)); id. at 531 (citing Brown v. Gilmore, 278 F.3d 362, 369 (4th Cir. 2002); Mensh v. Dyer, 956 F.2d 36, 40 (4th Cir. 1991)). 
amount of injury but lacked the citations within the cases themselves to support such an inquiry. ${ }^{133}$ Then, in addressing the dissent's argument, the court addressed the de minimis injury exception to excessive-force claims and seemed to allude to its inapplicability to Fourth Amendment claims. ${ }^{134}$ In juxtaposing the requirements of a Fourteenth Amendment excessive-force claim with the requirements of a Fourth Amendment excessive-force claim, the court stated that under the Fourth Amendment, a plaintiff need "simply prov[e] that the police acted unreasonably in violation of the Fourth Amendment," while under the Fourteenth Amendment, a plaintiff has "to prove that... [police] misconduct amounted to punishment and resulted in more than de minimis injury to him."135 Seemingly, the court, therefore, did not consider a de minimis injury analysis as part of Fourth Amendment jurisprudence in the circuit.

Confusingly, however, two years later in Sellers v. Waring-an opinion with no analysis and no oral argument-the Fourth Circuit affirmed the dismissal of a Fourth Amendment excessive-force claim on the basis that the plaintiff "fail[ed] to allege that he suffered more than de minimis injury." 136 As a result, while it seemed at most doomed and at least relegated to a factor for consideration by the Jones decision, the de minimis injury exception to Fourth Amendment excessive-force claims appears to remain valid in the Fourth Circuit. Indeed, no less than thirteen district court cases have recognized the exception since Sellers. ${ }^{137}$

133. See Brown, 278 F.3d at 369 (stating plaintiff "alleg[ed] no injury of any magnitude" but cited no authority to support this consideration under the Fourth Amendment); Mensh, 956 F.2d at 40 (stating "[i]t is undisputed that [plaintiff] suffered no physical injury as a result of the incident" but citing no authority to support this consideration under the Fourth Amendment).

134. Jones, 325 F.3d at 535 n.8.

135. Id. (citing Robles v. Prince George’s Cnty., 302 F.3d 262, 269 (4th Cir. 2002)).

136. 141 F. App’x. 121, 122 n.* (4th Cir. 2005) (per curiam) (citing Carter v. Morris, 164 F.3d 215, 219 n.3 (4th Cir. 1999)).

137. See Masterson v. Grant, No. 1:10CV445(LMB/JFA), 2011 WL 250562, at *6 (E.D. Va. Jan. 25, 2011) (holding "de minimis injuries cannot support a claim for excessive use of force" (citing Felton v. Chupik, No. 00-CV-1889, 2002 WL 32344335, at *4 (E.D. Va. Aug. 21, 2002))); Dunbar v. New Ellenton Police Dep’t, No. 9:08-2436-HFF-BM, 2010 WL 1073152, at *6 (D.S.C. Feb. 24, 2010) (rejecting as de minimis an injury that "was not overtly serious ... [and] was only of a superficial nature” (citing Norman v. Taylor, 25 F.3d 1259, 1263 (4th Cir. 1994) (en banc), abrogated by Wilkins v. Gaddy, 130 S. Ct. 1175 (2010) (per curiam))), adopted sub nom., Dunbar v. Allentown Police Dep’t, 2010 WL 1007475 (D.S.C. Mar. 18, 2010); Stevens v. Spartanburg Cnty. Prob., Parole, \& Pardon Servs., No. 6:09-795-HMH-WMC, 2010 WL 678953, at *9 (D.S.C. Feb. 23, 2010) ("[I]n the course of a lawful arrest, "the application of de minimis force, without more, will not support a claim for excessive force in violation of the Fourth Amendment."' (quoting Nolin v. Isbelt, 207 F.3d 1253, 1257 (11th Cir. 2000))); Fluker v. Owens, No. 9:08-3704-HFF-BM, 2009 WL 
2. Circuits that Generally Follow the Graham Analysis but Nevertheless Recognize an Injury Requirement or Injury-Based Consideration

\section{a. The Second Circuit}

The Second Circuit does not require an arrestee to demonstrate that he or she suffered an injury and has not adopted a de minimis injury exception to Fourth Amendment excessive-force claims. ${ }^{138}$ Instead, the Second Circuit has focused its "de minimis inquiry" on the amount of force the police officer uses, ${ }^{139}$ not the amount of injury the arrestee sustains. Indeed, in an unpublished opinion, the Second Circuit recognized that it has "permitted claims to survive summary judgment

3048719, at *6 (D.S.C. Sept. 23, 2009) (citing Thaddeus-X v. Wozniak, No. 99-1720, 2000 WL 712383, at *3 (6th Cir. May 23, 2000); Harper v. Showers, 174 F.3d 716, 719 (5th Cir. 1999)), aff'd, 361 F. App’x 510 (4th Cir. 2010); Corbin v. Woolums, No. 3:08cv173, 2008 WL 5049912, at *7 (E.D. Va. Nov. 25, 2008) ("[Plaintiff] suffered only temporary swelling and bruising-hardly a significant injury.”); Trull v. Smolka, No. 3:08CV460-HEH, 2008 WL 4279599, at *5 (E.D. Va. Sept. 18, 2008) ("Plaintiff has failed to allege more than a de minimis injury as required by the Fourth Amendment.” (citing Carter v. Morris, 164 F.3d 215, 219 n.3 (4th Cir. 1999))); Munyiri v. Haduch, 585 F. Supp. 2d 670, 677 (D. Md. 2008) ("Claims of a de minimis injury ... are insufficient.” (citing Norman, 25 F.3d at 1263; Carter, 164 F.3d at 219)); Lassiter v. Reece, No. 3:07-885-HFF-JRM, 2008 WL 2852164, at *4 (D.S.C. July 22, 2008) ("Plaintiff fails to show more than de minimis injury." (citing Ritchie v. Jackson, No. 95-3057, 1996 WL 585152, at *2 (4th Cir. 1996))), abrogated by Wilkins, 130 S. Ct. 1175; Batts v. Lyle, No. 3:06-1875-TLW-JRM, 2007 WL 2220402, at *4 (D.S.C. July 27, 2007) ("Plaintiff fails to show more than de minimis injury." (citing Ritchie, 1996 WL 585152, at *2; Joos v. Ratliff, 97 F.3d 1125, 1126 (8th Cir. 1996) (per curiam))) abrogated by Wilkins, 130 S. Ct. 1175; Grier v. Cappo, No. 4:05-0426-TLW-TER, 2007 WL 858868, at *6 (D.S.C. Mar. 19, 2007) ("Even assuming, arguendo, there was excessive force used during the arrest, a plaintiff may not recover, however, for only de minimis injuries." (citing Hudson, 503 U.S. at 4)), abrogated by Wilkins, 130 S. Ct. 1175; Vanover v. Blendowski, No. 3:052956-DCN-JRM, 2006 WL 3513682, at *5 (D.S.C. Dec. 5, 2006) ("Plaintiff fails to show more than de minimis injury.” (citing Ritchie, 1996 WL 585152, at *2; Joos, 97 F.3d at 1126 (per curiam))), abrogated by Wilkins, 130 S. Ct. 1175; Wilson v. Police Dep’t, No. Civ.A. 7:06-CV-00476, 2006 WL 2944940, at *1 (W.D. Va. Oct. 13, 2006) ("To state a claim that the use of handcuffs during arrest was unreasonable, plaintiff must allege facts indicating that he suffered more than de minimis injury.”); Mickle v. Ahmed, 444 F. Supp. 2d 601, 619 (D.S.C. 2006) (“A plaintiff may not recover, however, for only de minimis injuries." (citing Hudson v. McMillian, 503 U.S. 1, 4 (1992))). But see Ames v. Harford Cnty., No. RDB 09-1929, 2010 WL 1791547, at*7 (D. Md. May 4, 2010) (holding that Wilkins abrogated the de minimis injury exception).

138. See United States v. Walsh, 194 F.3d 37, 47 (2d Cir. 1999) (adopting a de minimis standard only in Eighth and Fourteenth Amendment excessive-force claims). The Second Circuit has held that an injury need not be permanent or severe to survive summary judgment. See Hayes v. N.Y.C. Police Dep’t, No. 06-0595-pr, 2007 WL 130332, at *1 (2d Cir. Jan. 16, 2007) (citing Maxwell v. City of New York, 380 F.3d 106, 108 (2d Cir. 2004)).

139. See Romano v. Howarth, 998 F.2d 101, 105 (2d Cir. 1993) (“[A] de minimis use of force will rarely suffice to state a constitutional claim.” (citing Hudson, 503 U.S. at 5-7)). 
where the only injury alleged is bruising." ${ }^{140}$ In yet another case, while the district court believed a plaintiff's injuries were insufficiently serious to rise to the level of a viable excessive-force claim, the Second Circuit held that summary judgment was inappropriate where the plaintiff alleged pain in her arm, lower back, and head as a result of the force used to effectuate an arrest. ${ }^{141}$ The Second Circuit exclusively relies on and articulates the Graham analysis of objective reasonableness along with its accompanying factors as the appropriate framework within which to analyze a claim. ${ }^{142}$ While the Second Circuit has not adopted a de minimis injury exception, it has not specifically rejected the theory.

In the gap left by the Second Circuit's failure to address the viability of a de minimis injury exception, district courts have turned to other circuits or inward to their sister courts. For example, in $\mathrm{Li} \mathrm{v}$. Aponte, the defendant argued that a plaintiff's injuries were de minimis as a matter of law and therefore not cognizable. ${ }^{143}$ Although the court ruled against the defendant, it nonetheless held, citing Fourth Circuit case law, that a "“de minimis injury can serve as conclusive evidence that de minimis force was used." "144 In other cases, the district courts have cited sister courts to support a de minimis injury exception. In Williams v. City of New York, for example, where a plaintiff alleged that, among other things, a police officer's use of aerosol mace constituted excessive force, the court found that the plaintiff's claims were not actionable because he had "not alleged any injuries from being sprayed with mace."145 In addition, the court found that the plaintiff's scrapes and bruises were no more than de minimis injuries and thus were not actionable. ${ }^{146}$ In support of both holdings regarding the lack of a Fourth Amendment claim due to the de minimis nature of the plaintiff's injury, the district court simply cited to other district courts within the circuit. ${ }^{147}$

\footnotetext{
140. Hayes, 2007 WL 130332 at *1 (citing Maxwell, 380 F.3d at 108).

141. Maxwell, 380 F.3d at 109-10.

142. See, e.g., McLaurin v. Falcone, No. 04-4849-CV, 2007 WL 247728, at *1 (2d Cir. Jan. 25, 2007); Jones v. Parmley, 465 F.3d 46, 61 (2d Cir. 2006).

143. No. 05 Civ. 6237(NRB), 2008 WL 4308127, at *6 n.41 (S.D.N.Y. Sept. 16, 2008).

144. Id. at *6 (quoting Carr v. Deeds, 453 F.3d 593, 606 (4th Cir. 2006)).

145. No. 05 Civ. 10230(SAS), 2007 WL 2214390, at *12 (S.D.N.Y. July 26, 2007) (citing Murphy v. Neuburger, No. 94 Civ. 7421(AGS), 1996 WL 442797, at *8 (S.D.N.Y. Aug. 6, 1996)).

146. Id. (citing Rincon v. City of New York, No. 03 Civ. 8276(LAP), 2005 WL 646080, at *5 (S.D.N.Y. Mar. 21, 2005); Cunningham v. Rodriguez, No. 01 Civ. 1123(DC), 2002 WL 31654960, at *5-6 (S.D.N.Y. Nov. 22, 2002); Bove v. New York City, No. 98 Civ. 8800(HB), 1999 WL 595620, at *6 (S.D.N.Y. Aug. 6, 1999)).

147. See cases cited supra notes 137-38 and accompanying text.
} 


\section{b. The Third Circuit}

While the Third Circuit has not directly addressed the de minimis injury exception by name, it has rejected the idea that "the absence of physical injury necessarily signifies that the force has not been excessive."148 Indeed, the Third Circuit routinely applies the Graham analysis for Fourth Amendment excessive-force claims and has only once referred to the term "de minimis injury" within that context. ${ }^{149}$ In an attempt to support its holding that an excessively tight handcuff claim can give rise to a viable Fourth Amendment excessive-force claim, the court in Kopec $v$. Tate sought to distinguish the facts before it from Glenn v. City of Tyler. The court noted that while the plaintiff in Kopec alleged an actual injury-permanent nerve damage to the wrist-the plaintiff in Glenn "failed to show more than a de minimis injury." 150 This arguably favorable, yet fleeting, reference is the only time the court has used the term "de minimis injury" within the context of Fourth Amendment excessive-force claims.

Although the court has conceptually rejected the de minimis injury exception, in Gulley v. Elizabeth City Police Department, it nevertheless noted that the magnitude of an arrestee's injury "is... one of the circumstances to be considered under the objective reasonableness standard set forth in Graham." ${ }^{\text {151 }}$ As a result, it appears the Third Circuit does not authorize an examination of an arrestee's injuries as a separate step in addition to the Graham analysis for excessive-force claims. Instead, the magnitude of the arrestee's injury is merely one of many factors to consider in the larger context of the analysis. ${ }^{152}$ It is unclear, however, when an arrestee's "absence of physical injury" 153 is considered. The court did not indicate whether a district court may consider such an absence when it rules on dispositive motions or whether

148. Sharrar v. Felsing, 128 F.3d 810, 822 (3d Cir. 1997) (citing Gumz v. Morrissette, 772 F.2d 1395, 1400-01 (7th Cir. 1985), abrogated by Lester v. City of Chicago, 830 F.2d 706 (7th Cir. 1987)), abrogated on other grounds by Curley v. Klem, 499 F.3d 199 (3d Cir. 2007).

149. Kopec v. Tate, 361 F.3d 772, 778 n.7 (3d Cir. 2004) (citing Glenn v. City of Tyler, 242 F.3d 307, 314 (5th Cir. 2001)).

150. Id. (citing Glenn, 242 F.3d at 314).

151. No. 07-1124, 2009 WL 2219266, at *2 n.2 (3d Cir. July 27, 2009) (affirming the district court's decision that rejected a de minimis injury exception argument by the defendant).

152. Id.

153. Id. 
the consideration falls to the fact-finder when assessing liability, credibility, or damages. ${ }^{154}$

\section{c. The Sixth Circuit}

The Sixth Circuit has implicitly rejected a de minimis injury exception for most Fourth Amendment excessive-force claims, though some of its district courts have failed to follow its lead. In Ingram v. City of Columbus, the district court found "as a matter of law that the officers did not apply excessive force... on the grounds that [the arrestees'] injuries were not sufficiently severe." ${ }^{55}$ The Sixth Circuit, however, reversed the district court's decision. ${ }^{156}$

The court reasoned that its precedent permitted a plaintiff to allege the use of excessive force "even where the physical contact between the parties did not leave excessive marks or cause extensive physical damage."157 Indeed, the court noted that there was no support in Sixth Circuit precedent for finding, as a matter of law, that police officers did not use excessive force simply because the plaintiff did not "suffer sufficient injuries." 158 The court went on to reject, as unsupported by the law, the district court's assertion that the "“nature and quality of the intrusion' must include consideration of the severity of any injury inflicted." 159 Indeed, the Sixth Circuit three years earlier had cited with approval an excerpt from a Seventh Circuit decision that stated "a state is not free to inflict... pains without cause just so long as it is careful to leave no marks." ${ }^{\prime 60}$ While it seems clear the Sixth Circuit has rejected a de minimis injury exception, some of the district courts within the circuit have failed to heed the ruling.

\footnotetext{
154. Although it arose within the Eighth Amendment context, the Third Circuit rejected the theory that where a prisoner's injury is de minimis, he does not have a viable constitutional claim. Smith v. Mensinger, 293 F.3d 641, 648 (3d Cir. 2002) (citing Hudson v. McMillian, 503 U.S. 1, 910 (1992)). The court, however, did not entirely dismiss the relevance of the amount of injury a plaintiff sustained in an excessive-force claim. Id. at 649. Indeed, the Smith court recognized that a fact-finder might properly consider the amount of injury a plaintiff suffered when, for example, assessing the credibility of the plaintiff's version of events. Id.

155. 185 F.3d 579, 597 (6th Cir. 1999).

156. Id. at 597-98.

157. Id. (citing Holmes v. City of Massillon, 78 F.3d 1041, 1048 (6th Cir. 1996)).

158. Id. at 597.

159. Id.

160. Holmes, 78 F.3d at 1048 (quoting Williams v. Boles, 841 F.2d 181, 183 (7th Cir. 1988)) (internal quotations marks omitted).
} 
For example, in Smith v. City of Chattanooga, when analyzing a plaintiff's Fourth Amendment excessive-force claim, the district court dutifully began its analysis with the analytical framework the Supreme Court outlined in Graham. ${ }^{161}$ After finishing the Graham inventory, however, the court, without citation to authority, pronounced that "[b]efore [the plaintiff could] make out a viable excessive force claim under ... the Fourth Amendment.... he [was] required to prove that [the police officer] used excessive force and proximately caused [the plaintiff] to suffer a significant injury. The injury must be more than de minimis."162 The court went on to find that the plaintiff had not met that burden. ${ }^{163}$ Similarly, in Lee v. Ritter, the court analyzed an arrestee's Fourth Amendment excessive-force claim. ${ }^{164}$ After listing the plaintiff's injuries of "multiple contusions, abrasions[,] and hematomas," the court stated in a footnote, but without a citation, that "[t]o prevail on an excessive force claim courts have found that the actual injury must be more than de minimis." 165

While the district courts' decisions discussed above may certainly be outliers, the Sixth Circuit has, like other circuits, carved out and created a special test for Fourth Amendment excessive-force claims related to "unduly tight or excessively forceful handcuffing during the course of a seizure.”166 To state a Fourth Amendment excessive-force claim related to handcuffing in the Sixth Circuit, a plaintiff must establish that: "(1) he or she complained the handcuffs were too tight; (2) the officer ignored those complaints; and (3) the plaintiff experienced 'some physical injury' resulting from the handcuffing." 167 It has yet to be seen whether the requirement for "some physical injury" will bleed into the analysis of the handcuffing of an arrestee, as in the Eighth Circuit.

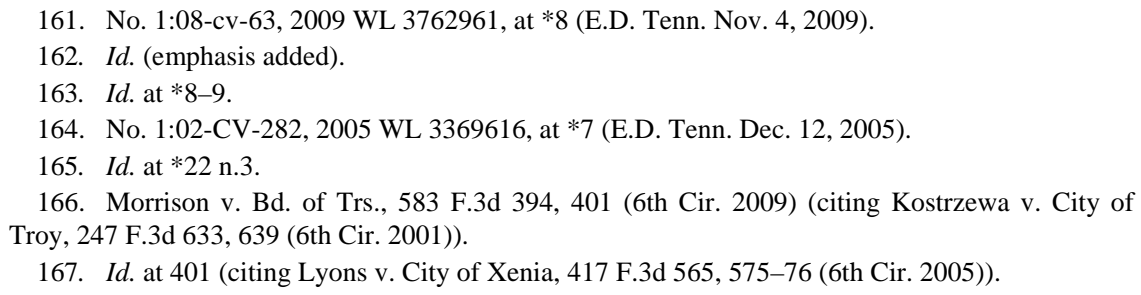




\section{d. The Eleventh Circuit}

Like the Sixth Circuit, the Eleventh Circuit has rejected the opportunity to fully embrace and apply a strict de minimis injury exception to Fourth Amendment excessive-force claims. In Lee v. Ferraro, the plaintiff alleged that a police officer slammed her head against the trunk of a car after she was handcuffed and subdued. ${ }^{168}$ In rejecting the district court's decision that the lack of injury rendered the force de minimis, the court reasoned that "objectively unreasonable force does not become reasonable simply because the fortuity of the circumstances protected the plaintiff from suffering more severe physical harm."169 In the same case, however, the court recognized a hybrid force-injury analysis, which would render meritless those cases where the force used and the injury sustained are both de minimis. ${ }^{170}$ This " $d e$ minimis force" exception arises out of Post $v$. City of Fort Lauderdale, ${ }^{171}$ a post-Graham case. When describing Post and its progeny, the court stated that the fact-intensive Graham inquiry may reject a Fourth Amendment excessive-force claim "when the facts show a minimal amount of force combined with a minor or nonexistent injury."172 The court left out of the pronouncement an inquiry into the injury the arrestee sustained. ${ }^{173}$ In its summation of the case law that supported the pronouncement, however, the court noted that part of its de minimis force exception included a review of "the injury inflicted"174 or the "nature of [the] injury." 175

In Draper v. Reynolds, the Eleventh Circuit clarified how the level of an arrestee's injury affects an analysis of whether a police officer's use of force under the Fourth Amendment was reasonable. ${ }^{176}$ Relying on a

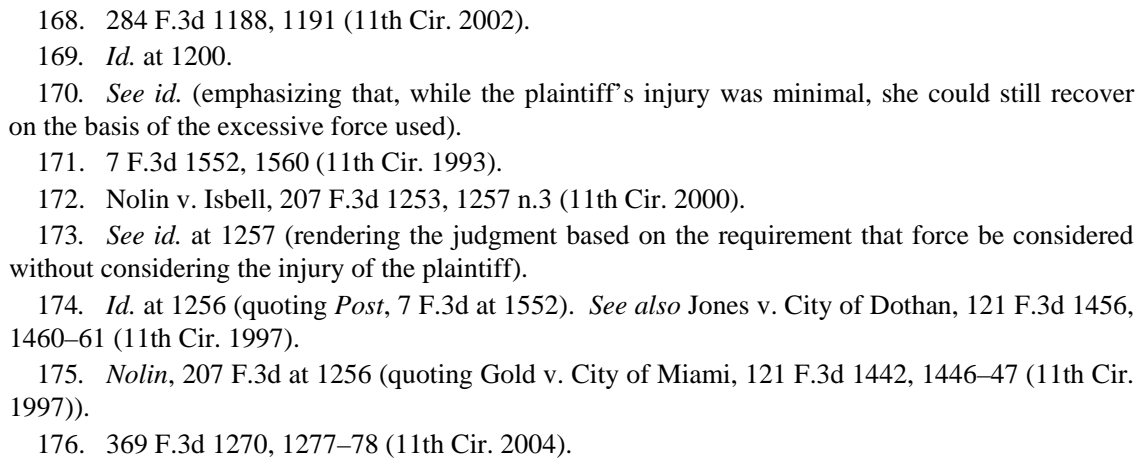


parenthetical from Lee, which in turn relied on a pre-Graham, preHudson decision, the Draper court articulated a tripartite test refining a Graham-like totality of the circumstances excessive-force analysis. ${ }^{177}$ The court instructed that when " determining if force was reasonable, courts must examine (1) the need for the application of force, (2) the relationship between the need and amount of force used, and (3) the extent of the injury inflicted." 178 The Eleventh Circuit declared reasonable a police officer's use of a Taser stun gun because the arrestee was "hostile, belligerent, and uncooperative" and did not suffer a "serious injury.","179

\section{e. The District of Columbia Circuit}

The Court of Appeals for the District of Columbia has indicated that the Graham test is the appropriate analytical framework. It has also opined, however, that the quantum of injury an arrestee sustains is a consideration when determining whether an arrestee asserts a cognizable excessive-force claim. For example, in Johnson v. District of Columbia, the court began its analysis of an excessive-force claim by quoting the Graham framework as the applicable controlling law. ${ }^{180}$ The D.C. Circuit further affixed an additional group of factors to consider when examining excessive-force claims. Quoting a pre-Graham case, the court stated that "such factors as the need for the application of force, the relationship between the need and the amount of force that was used, [and] the extent of injury inflicted'” should also guide a Fourth Amendment excessive-force analysis. ${ }^{181}$

A year later, in Wasserman v. Rodacker, an arrestee alleged that a police officer placed her hand on the arrestee's shoulder, "forced [his] arm behind his back, handcuffed him, and placed him under arrest.”182 The D.C. Circuit began its analysis by laying out the Graham framework. ${ }^{183}$ After analyzing the facts of the case in light of Graham,

177. Id. (quoting Lee v. Ferraro, 284 F.3d 1188, 1191 (11th Cir. 2002)).

178. Id. (footnotes omitted) (quoting Lee, $284 \mathrm{~F} .3 \mathrm{~d}$ at 1188).

179. Id. at 1273, 1278. But see Oliver v. Fiorino, 586 F.3d 898, 908 (11th Cir. 2009) (holding that a police officer used excessive force where he tasered an arrestee between eight and eleven times over a two-minute period and the arrestee died).

180. 528 F.3d 969, 974 (D.C. Cir. 2008).

181. Id. (alteration in original) (quoting Johnson v. Glick, 481 F.2d 1028, 1033 (2d Cir. 1973)).

182. 557 F.3d 635, 636-37 (D.C. Cir. 2009).

183. Id. at 641 . 
the D.C. Circuit affirmed summary judgment in favor of the police officer by finding that the arrestee "suffered no bruise or injury, which tends to confirm that [the police officer] did not use 'more force than reasonably appeared necessary' to secure [the arrestee's] compliance." ${ }^{\text {"184 }}$

The district court has dutifully employed this "tends to confirm" review when noting the quantum of injury arrestees suffered in excessive-force claims. For example, in Cromartie v. District of Columbia, an arrestee alleged that he was forced to the ground while being placed under arrest and restrained with handcuffs, which caused a "minor injury to [the arrestee's] wrist."185 In granting summary judgment on the arrestee's excessive-force claim, the district court conducted a cursory, Graham-like analysis of the facts and concluded that, under the circumstances of the arrest, the force that the police officer used was not excessive. ${ }^{186}$ The court noted that the arrestee's "minor injuries to his wrists further undermine[d] his excessive force claim.”187

3. Circuits that Strictly Follow the Graham Analysis and Do Not Consider the Arrestee's Injury

\section{a. The First Circuit}

Though the First Circuit has only once explored the de minimis injury concept as it related to a larger analysis of a Fourth Amendment excessive-force claim, it has not adopted or employed a de minimis injury exception in such claims. In finding that a district court's jury instruction was flawed because it included a "serious injury" requirement for an excessive-force claim, the First Circuit initially noted that liability can clearly be imposed absent a "serious injury."188 The court then announced the proper analysis of a Fourth Amendment excessive-force claim by requiring a review of whether the defendant's actions were “"objectively reasonable, viewed in light of the facts and circumstances confronting him and without regard to his underlying intent or

\footnotetext{
1996)).

185. 729 F. Supp. 2d 281, 284 (D.D.C. 2010).

186. Id. at 286 .

187. Id.

188. Bastien v. Goddard, 279 F.3d 10, 14 (1st Cir. 2002).
} 
motivation." "189 The court listed the relevant factors articulated in the Graham decision, ${ }^{190}$ but then stated that the "severity of the [plaintiff's] injury also may be considered." 191 The court clearly instructed that Fourth Amendment excessive-force claims are "“not precluded merely because only minor injuries were inflicted"” upon the plaintiff. ${ }^{192}$ The court's only reference to de minimis injuries came in a footnote supporting this point and discussing the Fifth Circuit's analysis of de minimis injuries. ${ }^{193}$ Indeed, each Fourth Amendment excessive-force case the First Circuit has reviewed since Bastien has simply referred to the Graham analysis as the proper analysis. ${ }^{194}$

\section{b. The Seventh Circuit}

While not referring to the exception by name, the Seventh Circuit has rejected the theory that a plaintiff cannot establish a Fourth Amendment excessive-force claim by alleging only a de minimis injury. For example, in Lanigan v. Village of East Hazel Crest, the plaintiff alleged that during a traffic stop, a police officer "administered one violent poke and push, and said to [the plaintiff], '[W]e know what to do with you." "195 The district court granted the motion to dismiss, and the plaintiff appealed. ${ }^{196}$ The Seventh Circuit favorably noted and affirmed the district court's recognition that "an excessive force claim does not require an injury, and therefore [the plaintiff] need not have been injured to have an excessive force claim.,"197

More recently, the Seventh Circuit specifically rejected the argument that an injury is a prerequisite to a Fourth Amendment excessive-force claim. ${ }^{198}$ In Baird v. Renbarger, the plaintiffs alleged that a police officer used excessive force by wielding a submachine gun to effectuate

\footnotetext{
189. Id. (quoting Alexis v. McDonald's Rests. of Mass., 67 F.3d 341, 352 (1st Cir. 1995)).

190. Id. (quoting Graham v. Connor, 490 U.S. 386, 396 (1989)).

191. Id. (citing Dean v. City of Worcester, 924 F.2d 364, 369 (1st Cir. 1991)).

192. Id. (quoting Alexis, 67 F.3d at 352).

193. Id. at $14 \mathrm{n} .7$ (citing Glenn v. City of Tyler, 242 F.3d 307, 314 (5th Cir. 2001)).

194. See, e.g., Raiche v. Pietroski, 623 F.3d 30, 36 (1st Cir. 2010); Morelli v. Webster, 552 F.3d

12, 23 (1st Cir. 2009); Jennings v. Jones, 499 F.3d 2, 11 (1st Cir. 2007); Flowers v. Fiore, 359 F.3d 24, 34 (1st Cir. 2004).

195. 110 F.3d 467, 474 (7th Cir. 1997) (second alteration in original).

196. Id. at $470-71$.

197. Id. at 470 n.3 (citing 913 F. Supp. 1202, 1209 (N.D. Ill. 1996)).

198. Baird v. Renbarger, 576 F.3d 340, 344 (7th Cir. 2009).
} 
a search warrant despite the nonviolent nature of the suspected crime and the lack of suspicion that the suspects were armed or dangerous. ${ }^{199}$ After discussing Graham's “objective reasonableness" test, the court specifically foreclosed a de minimis injury exception in the Seventh Circuit by holding that "[p]laintiffs need not show physical injury in order to sustain an excessive force claim."200 The appropriate analysis, the court reasoned, considers "whether [the seizure] was objectively reasonable, judged from the perspective of a reasonable officer on the scene."201

Few district courts in the Seventh Circuit have been presented with the argument that a de minimis injury cannot support a Fourth Amendment excessive-force claim. Of the district courts that have dealt with the issue, the court's decision in Davis v. Peoria County is representative of the district courts' acknowledgment of the Seventh Circuit's approach to the de minimis injury exception. In Davis, the plaintiff alleged that during a confrontation that lasted between one and two minutes, police officers threw her to the ground, pulled her arm behind her back, kneed her in the thigh, and bit her shoulder. ${ }^{202}$ An examination by a nurse determined that the plaintiff's "right wrist and left cheek were slightly swollen, and that her right outer thigh was reddened." ${ }^{203}$ After being released from jail, the plaintiff visited a doctor who found that she "had pain, swelling, and bruising or a contusion of her right wrist, blunt injuries, and moderate elevation of systolic blood pressure."204

In support of a de minimis injury exception, the defendants relied on the Seventh Circuit's Pattern Jury Instructions for Fourth and Fourteenth Amendment excessive-force claims. ${ }^{205}$ The jury instructions, the defendants argued, permitted a jury to consider the harm a plaintiff sustained when determining whether a particular use of force was objectively reasonable. ${ }^{206}$ As a result, the police officer posited that an arrestee must have incurred more than a de minimis injury to have a valid

199. Id. at 342-44.

200. Id. at 344 .

201. Id. (citing Graham v. Connor, 490 U.S. 386, 396 (1989)).

202. No. 08-cv-1118, 2009 WL 3258318, at *1 (C.D. Ill. Oct. 8, 2009).

203. Id. at $* 2$.

204. Id. at $* 3$.

205. Id. at *5.

206. Id. 
excessive-force claim. ${ }^{207}$ In rejecting the police officer's argument, the district court reasoned that the committee comments appended to the instructions "express[ed] reservations about the use of the 'harm' element, citing case law strongly suggesting that 'harm' to the [arrestee] is not an element of an excessive force claim."208 The court held that even if the arrestee suffered only de minimis injuries, it does not necessarily follow that she is unable to succeed on a Fourth Amendment excessive-force claim. ${ }^{209}$

\section{c. The Ninth Circuit}

Though it has never directly entertained an argument in support of a de minimis injury exception to Fourth Amendment excessive-force claims, the Ninth Circuit has indicated that it would likely reject the idea. $^{210}$ In Headwaters Forest Defense v. County of Humboldt, police officers used pepper spray against protesters who were practicing nonviolent civil disobedience. ${ }^{211}$ The district court granted the defendants' motion for judgment as a matter of law and reasoned that the use of pepper spray only minimally intruded upon the protestors' bodily integrity because "it did not involve the threat of 'deadly force or even ... a significant level of physical force." "212 Instead, the district court held that the force simply resulted in " "transient pain without significant risk of physical injury.,"213 The Ninth Circuit reversed and held that although a plaintiff may only be entitled to nominal damages if he has not incurred an actual injury, he may nevertheless have a valid Fourth Amendment excessive-force claim. ${ }^{214}$ The court observed that the proper analysis of a Fourth Amendment excessive-force claim begins with the Graham objective-reasonableness test and its accompanying

207. Id.

208. Id. (quoting FED. CIV. JURY INSTR. 7TH CIR. § 7.08 cmt. (2005)).

209. Id. at *6. The court did not clearly determine whether the Fourth Amendment or the Fourteenth Amendment governed plaintiff's claims; instead, the court analyzed whether the force used was objectively reasonable. Id.

210. See, e.g., Headwaters Forest Def. v. Cnty. of Humboldt, 240 F.3d 1185, 1205 (9th Cir. 2000), vacated and remanded on other grounds, 534 U.S. 801 (2001).

211. Id. at 1194-95.

212. Id. at 1199 (quoting Headwaters Forest Def. v. County of Humboldt, No. C-97-3989-VRW, 1998 WL 754575, at *4 (N.D. Cal. Oct. 26, 1998)).

213. Id. (quoting Headwaters, 1998 WL 754575 at *4).

214. Id. at 1198-99 (citing Lavez v. City of Los Angeles, 946 F.2d 630, 640 (9th Cir. 1991)). 
factors. $^{215}$ In describing the heart of the analysis, the court focused on the force the police officer uses balanced against the need for the force. $^{216}$ Notably absent from both the court's list of Graham factors, as well as the court's characterization of the heart of the Graham analysis, was a focus on the quantum of injury the arrestee sustained. ${ }^{217}$ The court, however, did not completely reject this consideration. ${ }^{218}$ Instead, the court determined that the nature and risk of injury a particular type of force poses is a factor that may be considered when evaluating the need for force. ${ }^{219}$

A year later, however, in Arpin v. Santa Clara Valley Transportation Agency, the Ninth Circuit seemed to open the door to including an analysis of whether an arrestee suffered an actual injury in an excessiveforce claim. ${ }^{220}$ In Arpin, an arrestee stiffened her arm and attempted to pull free from the arresting officer's grasp while being placed in handcuffs. $^{221}$ The arrestee alleged that as a result of the arresting officer's use of force in the course of handcuffing her, she suffered an injury. ${ }^{222}$ The district court held that the police officer's use of force was objectively reasonable under the circumstances and granted summary judgment in favor of the defendant. ${ }^{223}$ In reviewing the district court's decision, the Ninth Circuit analyzed the plaintiff's excessive-force claim by citing to and articulating the Graham "'objective reasonableness"” test, along with its standard accompanying factors. ${ }^{224}$ The court found that the arrestee's legally impermissible resistance rendered the police officer's use of force objectively reasonable. ${ }^{225}$ The court further noted that the plaintiff "[did] not provide any medical records to support her claim that she suffered injury as a result of being handcuffed," which weakened her claim. ${ }^{226}$ Thus, the plaintiff "failed to meet her burden of

215. Id. at 1198 (quoting Graham v. Connor, 490 U.S. 386, 397 (1989)).

216. Id. at 1199 (quoting Liston v. Cnty. of Riverside, 120 F.3d 965, 976 n.10 (9th Cir. 1997)).

217. See id. (quoting Liston, 120 F.3d at 976).

218. Id.

219. Id.

220. 261 F.3d 912, 921-22 (9th Cir. 2001).

221. Id. at 921 (noting that arrestee did not refute police officer's report that arrestee "stiffened her arm and attempted to pull it away").

222. Id. at 922 .

223. Id. at 921.

224. Id. (quoting Graham v. Connor, 490 U.S. 386, 388, 396 (1989)).

225. See id. (citing United States v. Span, 970 F.2d 573, 580 (9th Cir. 1992)).

226. Id. at 922 (citing Foster v. Metro. Airports Comm’n, 914 F.2d 1076, 1082 (8th Cir. 1990)). 
proof of providing specific facts to show that the force used was unreasonable or that she sustained actual injuries.,227

The court's inclusion of the lack of "actual injuries" as support for affirming summary judgment seems to have been simply an additional reason that does not stand alone. The court appears to have merely summarized the lack of evidence that supported the claims of excessive force and injury. Indeed, the court could have supported its affirmation of summary judgment in favor of the police officer by simply concluding that the plaintiff failed to provide specific facts to show that the force used was unreasonable. Nevertheless, as has become the problem with the circuits' imprecision regarding the proper place for a review of an arrestee's injury, the district courts within the Ninth Circuit have cited to this portion of the Arpin decision and applied it inconsistently. ${ }^{228}$

While the court's opinion in Arpin arguably justified the district court's analysis of whether an arrestee sustained "actual injuries" in a Fourth Amendment excessive-force claim, in Bryan v. MacPherson, the court reaffirmed Headwaters Forest Defense by stating that "force can be unreasonable even without physical blows or injuries."229 The Bryan court was faced with determining whether the use of a Taser stun gun could constitute excessive force. ${ }^{230}$ The plaintiff in Bryan suffered fractured teeth and facial contusions as a result of falling to the ground after the defendant police officer's Taser incapacitated him. ${ }^{231}$ The court nonetheless examined whether the experience of being stunned by the Taser is independently of a nature and quality that can give rise to an excessive force claim. ${ }^{232}$ After describing a Taser's mechanical operation, the court discussed the effects of the weapon on a target. ${ }^{233}$

227. Id. (emphasis added).

228. Compare Halbert v. Cnty. of San Diego, No. 07cv1607-L(WVG), 2010 WL 1292163, at *13 (S.D. Cal. Mar. 30, 2010) (explaining that in Arpin "summary judgment for the defense was not based solely on the plaintiff's failure to support her claim of injury with medical records" (citing Arpin, 261 F.3d at 922)), with Brooks v. Haggett, No. C 07-2615 SBA (PR), 2009 WL 688855, at *6 (N.D. Cal. Mar. 16, 2009) (noting that Arpin stands for the rule that an "injury claim cannot survive summary judgment where plaintiff provides no medical records to support claim that she was injured as a result of being handcuffed" (citing Arpin, 961 F.3d at 922)).

229. Bryan, 630 F.3d 805, 824 (9th Cir. 2010) (citing Headwaters Forest Def. v. Cnty. of Humboldt, 240 F.3d 1185, 1199 (9th Cir. 2000), vacated and remanded on other grounds, 534 U.S. 801 (2001); Tekle v. United States, 511 F.3d 839, 845 (9th Cir. 2007)).

230. Id. at 809.

231. Id. at 822 .

232. See id. at 810-12.

233. Id. at 824-26. 
The court noted the "physiological effects, the high levels of pain, and foreseeable risk of physical injury" in rejecting the defendant's argument that because those effects are only temporary, they constitute an insignificant level of force. ${ }^{234}$ To the contrary, although the court recognized the utility of Tasers, it held that the intense pain, immobilization, disorientation, loss of balance, and weakness they cause can constitute excessive force pursuant to an analysis of the circumstances under which they are deployed. ${ }^{235}$

\section{Wilkins v. Gaddy}

Recently, the Supreme Court had the opportunity to address the viability of a de minimis injury exception to excessive-force claims within the Eighth Amendment context, thus revisiting Hudson. In Wilkins v. Gaddy, a prisoner filed a pro se complaint alleging that a corrections officer threw him onto a concrete floor and "sproceeded to punch, kick, knee[,] and choke'” him. ${ }^{236}$ The complaint further alleged that the prisoner suffered " "a bruised heel, lower back pain, increased blood pressure, as well as migraine headaches and dizziness' and 'psychological trauma and mental anguish including depression, panic attacks[,] and nightmares of the assault., ${ }^{237}$ In applying Fourth Circuit precedent, the district court dismissed the complaint because plaintiff's allegations of a bruised heel, back pains, and headaches were no more than de minimis injuries. ${ }^{238}$ The Fourth Circuit affirmed. ${ }^{239}$

In reversing the Fourth Circuit, the Supreme Court reaffirmed Hudson. $^{240}$ The Court began by recounting its Hudson decision and why the Fifth Circuit's decision that gave rise to Hudson was in error. ${ }^{241}$ The Court noted that constitutional deficiency arose from the Fifth Circuit's imposing a "significant injury"” requirement on Eighth Amendment excessive-force claims and holding that the prisoner's injuries were "too

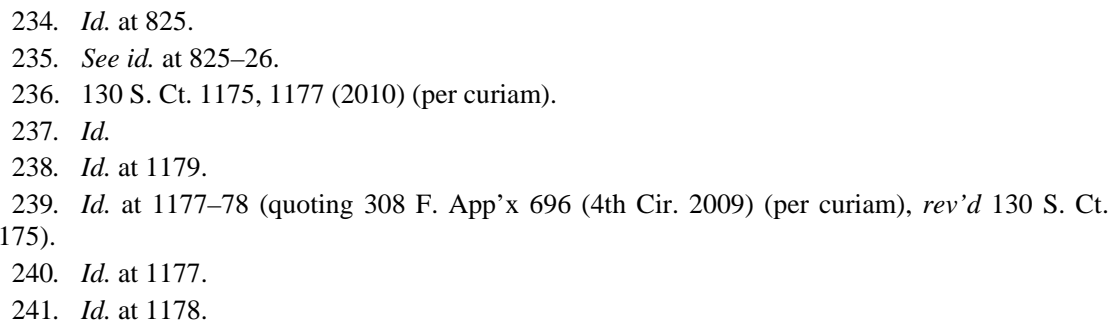


'minor' to warrant relief."242 Instead, the Court reiterated that the "“core judicial inquiry'... was not whether a certain quantum of injury was sustained, but rather 'whether force was applied in a good-faith effort to maintain or restore discipline, or maliciously and sadistically to cause harm." 243 The core judicial inquiry focuses on force, the Court reasoned, because an inmate does not lose his or her Eighth Amendment rights to be free from excessive force simply because he or she is fortunate enough to "escape without serious injury."244 Indeed, recognizing a de minimis injury exception to Eighth Amendment excessive-force claims "improperly bypasses this core inquiry." 445 However, the court did not dismiss the implication of a lack of injury. ${ }^{246}$ The quantum of injury may be useful as a factor to determine whether the force could have been thought necessary or may "provide some indication of the amount of force applied."247 Allegations of de minimis force coupled with "no discernible injury almost certainly fail[] to state a valid excessive force claim."248

\section{A De Minimis Injury Exception to Fourth Amendment Excessive- Force Claims Permits an Unconstitutional Focus on the Arrestee's Injury}

1. The Supreme Court's Jurisprudence Demonstrates that the De Minimis Injury Exception Lacks a Constitutional Basis

Taken together, the Supreme Court's jurisprudence regarding excessive force, regardless of the applicable amendment, demonstrates that there is no constitutional basis for a de minimis injury exception to Fourth Amendment excessive-force claims. While some circuits continue to require or permit an analysis of the extent of the physical or psychological injury the arrestee incurs, a court's analysis cannot turn on the magnitude of the injury. Instead, the analysis must focus on the force used and its objective reasonableness under the circumstances. Indeed,

242. Id. (quoting Hudson v. McMillian, 929 F.2d 1014, 1015 (5th Cir. 1990) (per curiam)).

243. Id. (quoting Hudson v. McMillian, 503 U.S. 1, 7 (1992)).

244. Id. at $1178-79$.

245. Id. at 1179 (citing Hudson, 503 U.S. at 9).

246. Id. at 1178 (citing Hudson, 503 U.S. at 7).

247. Id.

248. Id. (citing Hudson, 503 U.S. at 9). 
those circuits that require or permit district courts to grant dispositive motions in favor of a defendant because the plaintiff lacks some physical or psychological injury ignore the dictates of Hudson, Wilkins, and, more applicable, Graham.

Hudson and Wilkins, though discussing Eighth Amendment excessive-force claims, nevertheless demonstrated the pragmatic implication of examining the injury an arrestee incurs. In discussing the validity of requiring a significant injury for a cognizable Eighth Amendment excessive-force claim, the Hudson Court realized that some force, by its very nature, may be unlikely to cause a physical injury. ${ }^{249}$ Requiring that a plaintiff sustain some indefinite amount of injury will overlook some constitutional violations of a citizen's right to be free from excessive force. ${ }^{250}$ Indeed, focusing on and requiring an injury avoids imposing constitutional liability by permitting force "no matter how diabolic or inhuman, [so long as it] inflict[s] less than some arbitrary quantity of injury." 251 This reality must confine the jurisprudence of Fourth Amendment excessive-force claims to just what the claim suggests - that the state used unnecessary and disproportionate force in arresting an otherwise free citizen. To do otherwise would place in the state's hands the power to use virtually any amount or manner of force to detain its citizens. To be sure, the Graham decision itself requires nothing less than an absolute prohibition of the de minimis injury exception to Fourth Amendment excessive-force claims.

As discussed above, when articulating the proper analysis for a Fourth Amendment excessive-force claim, the Court in Graham placed its focus on the police officer's actions ${ }^{252}$ - the very actions that manifest the force used to detain an arrestee. The Graham Court, like in Wilkins, determined that the proper constitutional analysis lay not in the result of the force, but instead in whether the police officer's actions and concomitant force used to detain the arrestee were "'objectively reasonable' in light of the facts and circumstances confronting [the

\footnotetext{
249. Hudson, 503 U.S. at 9.

250. Id.

251. Id.

252. See Graham v. Connor, 490 U.S. 386, 397 (1989) (citing Scott v. United States, 436 U.S. 128, 137-39 (1978); Terry v. Ohio, 392 U.S. 1, 21 (1968)); see also Bryan N. Georgiady, Note, An Excessively Painful Encounter: The Reasonableness of Pain and De Minimis Injuries for Fourth Amendment Excessive Force Claims, 59 SyRACUSE L. REV. 123, 151 (2008) (citing Graham, 490 U.S. at 388).
} 
officer].”253 The analysis, therefore, revolves around what occurred between the police officer and the arrestee at the time of the arrest and the degree of force chosen to detain the arrestee. It does not consider the "post-force" damage caused by the force.

To facilitate the analysis of whether the force itself was excessive, the Court articulated several factors. ${ }^{254}$ Those factors also focus on whether the force was appropriate in light of the situation the police officer faced at the time of the arrest. ${ }^{255}$ The factors do not assess the continuing physical or psychological impact of the force on the arrestee. $^{256}$ Instead, the factors examine the circumstances confronting the police officer before he or she decided to use force to detain the arrestee and whether the degree of force used was more than was necessary under those circumstances. ${ }^{257}$ The magnitude of the injury an arrestee sustained sheds no light on whether the amount of force a police officer used was disproportionate to the need for force. ${ }^{258}$ During those moments in which a police officer uses force, it is either excessive or not excessive based on the circumstances facing the officer. ${ }^{259}$ Any continuing injury or lack of injury that occurs after the use of force is purely a by-product of the force and temporally unrelated to whether the degree of force was appropriate. Certainly, the Graham Court had the opportunity to adopt a test that reviewed, among other things, the extent of the injury the arrestee sustained. ${ }^{260}$ It passed on the offer. ${ }^{261}$

253. Graham, 490 U.S. at 397 (citing Scott, 436 U.S. at 137-39; Terry, 392 U.S. at 21).

254. The Court required consideration of "the severity of the crime at issue, whether the suspect poses an immediate threat to the safety of the officers or others, and whether he is actively resisting arrest or attempting to evade arrest by flight.” Id. at 396 (citing Tennessee v. Garner, 471 U.S. 1, 89 (1985)).

255. Id. ("[P]roper application requires careful attention to the facts and circumstances of each particular case.”).

256. See id.; see also Bartram v. Wolfe, 152 F. Supp. 2d 898, 903 n.7 (S.D. W. Va. 2001) (" $\mathrm{T}]$ he focus is on the objective reasonableness of the force used, not the scale of the injury." (citing Saucier v. Katz, 533 U.S. 194, 208 (2001), overruled on other grounds by Pearson v. Callahan, 555 U.S. 223 (2009))).

257. Graham, 490 U.S. at 396; see also Gulley v. Elizabeth City Police Dep’t., No. 04-4445 (JLL), 2006 WL 3694588, at *8 (D.N.J. Dec. 13, 2006) (" $[T]$ he focus is on the extent of the force applied ....”), aff'd, No. 07-1124, 2009 WL 2219266 (3d Cir. July 27, 2009).

258. For example, a police officer firing his gun at a suspected, but otherwise peaceful, jaywalker would be no less responsible for using excessive force if the jaywalker was fortunate enough to avoid being hit by the bullet.

259. See, e.g., Mickle v. Ahmed, 444 F. Supp. 2d 601, 619 (D.S.C. 2006) (recognizing that " $[t]$ he focus is on reasonableness at the moment" of the arrest (citing Graham, 490 U.S. at 396)).

260. See Graham, 490 U.S. at 390-92.

261. See id. at 396. 
2. Courts that Require an Arrestee Suffer Some Quantum of Injury Append an Added Harm to a Stand-Alone, Constitutional Violation

To inject a review and determination of the amount of physical or psychological injury an arrestee sustains into the analysis of a Fourth Amendment excessive-force claim is akin to crossbreeding modern tort burdens - which requires a physical or psychological harm-with a constitutional claim. ${ }^{262}$ One's constitutional right to be free from excessive force while being arrested is a right unto itself $^{263}$-a right that can be violated without regard to any physical or psychological injury. The "'intrusion on the individual's Fourth Amendment interests",264 is the harm a free citizen suffers when excessive force is used to detain him. ${ }^{265}$ The intrusion itself carries with it liability for the state as the intruder. ${ }^{266}$ The violation of this right, then, cannot be tied to a modern tort prerequisite that requires and examines the magnitude of the physical or psychological impact of the violation. Indeed, a mingling of modern tort expectations regarding injury with Fourth Amendment rights is precisely what appears to be taking place in those circuits that require an injury or recognize a de minimis injury exception to Fourth Amendment excessive-force claims. ${ }^{267}$

Nowhere is this better demonstrated than the Fifth Circuit's reintroduction of the concept of "serious injury"-though using a different adjective-into the analysis of Fourth Amendment excessiveforce claims. In Flores, ${ }^{268}$ the Fifth Circuit held that psychological injuries could be used to establish the circuit's "injury" requirement for Fourth Amendment excessive-force claims. $^{269}$ The Fifth Circuit,

262. See Georgiady, supra note 252, at 158-59.

263. See generally id. at $1661 \mathrm{n} .253$ (discussing Professor Anthony Amsterdam's assessment of the "atomistic" view of the Fourth Amendment as compared with the "regulatory" view of the Fourth Amendment (quoting Anthony Amsterdam, Perspectives on the Fourth Amendment, 58 MinN. L. REV. 349, 374 (1974))).

264. Graham, 490 U.S. at 396 (quoting Tennessee v. Garner, 471 U.S. 1, 8 (1985)).

265. See id. (balancing the citizen's interest "against the countervailing governmental interests at stake" (citing Garner, 471 U.S. at 8)).

266. See Georgiady, supra note 252, at 159 ("[O]fficers may only be held liable in tort if their conduct is first determined to be violative of a known constitutional right." (citing Saucier v. Katz, 533 U.S. 194, 200-01 (2001), overruled on other grounds by Pearson v. Callahan, 555 U.S. 223 (2009)).

267. See generally Georgiady, supra note 252, at 158-59.

268. See supra Part II.C.1.a.

269. Flores v. City of Palacios, 381 F.3d 391, 400-01 (5th Cir. 2004). 
however, seemed to adopt a burden of proof similar to that imposed on a plaintiff in a tort claim of negligent infliction of emotional distress. ${ }^{270}$ In holding that psychological injuries could satisfy the circuit's "injury" requirement, the court found that minor psychological injuries alone could not be the basis of a valid claim. ${ }^{271}$ Instead, psychological injuries must be "substantial... [to] satisfy the injury element" of a Fourth Amendment claim. ${ }^{272}$ The Fifth Circuit noted that the plaintiff alleged "post-traumatic stress disorder, mental anguish, headaches, and nightmares" as a result of the excessive force. ${ }^{273}$ Apparently, these are the significant psychological injuries that could meet the test articulated in Flores. ${ }^{274}$ Other psychological harms, such as the fright experienced while being subjected to excessive force; intense but nonpermanent pain resulting from the use of excessive force; or a general distrust of the state and its use of police powers after experiencing excessive force would seemingly not rise to the level of a "substantial injury." Nevertheless, by reintroducing an obligatory higher quantum of injury for psychological injuries, Flores reveals the Fifth Circuit's fixation on imposing modern tort burdens and expectations upon Fourth Amendment excessive-force claims.

Certainly, a tort claim like negligent infliction of emotional distress protects an injured party's interest in being made whole as a result of another's causing him a loss. ${ }^{275}$ A Fourth Amendment claim, however, protects one's individual interest in not being subjected to excessive force while being arrested. ${ }^{276}$ The state's use of more force than is necessary to effectuate the arrest of a free citizen, by itself, is a harm for which a plaintiff may seek redress. Therefore, the analysis of a Fourth

270. Compare id. at 400-01, with RESTATEMENT (SECOND) OF TORTS § 436 A (1965) ("If the actor's conduct is negligent as creating an unreasonable risk of causing either bodily harm or emotional disturbance to another, and it results in such emotional disturbance alone, without bodily harm or other compensable damage, the actor is not liable for such emotional disturbance.”), and id. $\S 313$.

271. See Flores, 381 F.3d at $400-01$.

272. Id.

273. Id. at 395.

274. See id. at 399 (stating that plaintiff sufficiently alleged a claim).

275. Restatement (SECOND) OF TORTS § 313(1) (1965) ("If the actor unintentionally causes emotional distress to another, he is subject to liability to the other for resulting illness or bodily harm ....”).

276. Graham v. Connor, 490 U.S. 386, 388 (1989). But see Anthony Amsterdam, Perspectives on the Fourth Amendment, 58 MinN. L. REV. 349, 369 (1974) (contending that "the regulation of police behavior is what the [F]ourth [A]mendment is all about”). 
Amendment excessive-force claim must focus only on the amount of force used, irrespective of the resulting injury. Including a requirement that some injury results from the excessive force simply adds a second harm to which the victim must be subjected. This addition of a second required harm ignores a free citizen's free-standing constitutional interest in being free from the state's use of excessive force during an arrest.

Similar to the requirement of a substantial injury in the Fifth Circuit, the Eleventh Circuit has implicitly reintroduced the concept of "significant injury."277 As part of its analysis of excessive-force claims, the Eleventh Circuit requires an examination of "the extent of the injury inflicted"278 yet fails to specifically define the quantum of injury required. District courts left wondering what level of injury is necessary are forced to comb through cases like Draper for clues. Their search will reveal that the Eleventh Circuit, in part, supported its conclusion that the police officer's use of force in Draper was not excessive because it "did not inflict any serious injury." 279 Indeed, district courts in the Eleventh Circuit, at least in the context of the use of Tasers like in Draper, are likely to find that so long as an arrestee's injuries are not serious, the extent of the injury is de minimis. ${ }^{280}$

The Supreme Court must, as it did in the context of the Eighth Amendment, explicitly state that a de minimis injury exception does not exist within the context of Fourth Amendment excessive-force claims. If the Court fails to do so, district courts will continue to review the magnitude of an arrestee's injuries despite the dictates of Graham, as was the case with Hudson until Wilkins. Indeed, as is demonstrated above, district courts will continue to review the magnitude of an arrestee's injuries even in those circuits that have implicitly or explicitly rejected such a review. For example, while the Second ${ }^{281}$ and Sixth Circuits $^{282}$ have rejected an examination of the amount of injury an arrestee sustained as part of a Fourth Amendment claim, district courts in those circuits have nonetheless incorporated the de minimis injury

277. See supra Part II.C.2.d.; see, e.g., Crenshaw v. Lister, 556 F.3d 1283, 1288 (11th Cir. 2009) (per curiam).

278. Id. at 1291 (quoting Hadley v. Gutierrez, 526 F.3d 1324, 1329 (11th Cir. 2008)).

279. Draper v. Reynolds, 369 F.3d 1270, 1278 (11th Cir. 2004) (emphasis added).

280. See id.

281. See supra Part II.C.2.a.

282. See supra Part II.C.2.c. 
exception into their analyses. ${ }^{283}$ Failing to reaffirm the lack of an examination of the arrestee's injury in the Graham analysis permits the consideration of the quantum of injury sustained by an arrestee. This will, in turn, lead to additional exceptions based on an arrestee's lack of injury. Indeed, exceptions like the Eighth Circuit's heightened pleading requirements in handcuffing cases may be employed in other circumstances. As new, nonlethal weapons are created and their effects prove difficult to measure, courts will likely create a new patchwork of tests perhaps requiring long-term, permanent, serious, or substantial injuries.

\section{THE DE MINIMIS INJURY EXCEPTION TO FOURTH AMENDMENT EXCESSIVE-FoRCE CLAIMS Must BE ABANDONED BECAUSE FUTURE NONLETHAL WEAPONS WILL NOT CAUSE THE QUANTUM OF INJURY NECESSARY TO OVERCOME THE EXCEPTION}

\section{A. Background}

The folly of recognizing a de minimis injury exception to Fourth Amendment excessive-force claims emerges clearly when one reviews new nonlethal-weapon technology. Undoubtedly, the development and use of nonlethal weapons is on the rise. ${ }^{284}$ Indeed, with the confluence of the "War on Terror," military spending, and private contractors vying for development rights, it is only a matter of time before cutting edge technologies appear in the hands of domestic law enforcement. ${ }^{285}$ If the rise in the use and reliance on Tasers is any indication, ${ }^{286}$ once introduced, domestic law enforcement will employ these technologies with vigor. Indeed, as is discussed below, the drive to develop new nonlethal weapons illustrates the need to consider not only the

283. See, e.g., Smith v. City of Chattanooga, No. 1:08-cv-63, 2009 WL 3762961, at *8 (E.D. Tenn. Nov. 4, 2009); Li v. Aponte, No. 05 Civ. 6237(NRB), 2008 WL 4308127, at *6 (S.D.N.Y. Sept. 16, 2008); Williams v. City of New York, No. 05 Civ. 10230(SAS), 2007 WL 2214390, at *12 (S.D.N.Y. July 26, 2007); Lee v. Ritter, No. 1:02-CV-282, 2005 WL 3369616, at *7 n.3 (E.D. Tenn. Dec. 12, 2005).

284. See Nick Lewer \& Neil Davison, Non-Lethal Technologies: An Overview, DISARMAMENT F., no. 1, 2005, at 37, 37.

285. Don Hummer, Policing and "Hard" Technology, in New Technology of Crime, LaW AND SOCIAL CONTROL 133, 133 (James M. Byrne \& Donald J. Rebovich eds., 2007).

286. See U.S. Dep'T OF Justice, RevieW of the Department of Justice's Use of LessLETHAL WEAPONS 15 (2009), available at http://www.justice.gov/oig/reports/plus/e0903/final.pdf; Connie Paige, Police Report Expanded Use of Tasers, Boston GloBe, Feb. 22, 2009, at 1. 
constitutional basis for the de minimis injury exception, but the practical basis as well. As a result, understanding these nonlethal weapons and the injury — or lack of injury - they cause is key to discussing the practical viability of a de minimis injury exception to Fourth Amendment excessive-force claims.

Any discussion of nonlethal weapons, however, requires a standard definition of the term, as it inevitably provokes various ideas and preconceptions depending on one's point of view. ${ }^{287}$ This portion of the Article discusses those weapons that "are designed not to destroy or kill but to incapacitate."288 Stated differently, it focuses on those weapons that are intended to avoid fatalities ${ }^{289}$ or drastically minimize or eliminate the physical injury that suspects suffer when taken into custody. ${ }^{290}$ Because virtually any nonlethal weapon could cause fatalities, ${ }^{291}$ this discussion focuses on those weapons whose intended purpose and design are as described above. This Article further focuses on the avant-garde technologies that have only recently been introduced to domestic law enforcement and that are in the development or initial stage of deployment, often in military theaters.

Nonlethal weapons come in various forms and are categorized in various ways. Most common nonlethal weapons are categorized based on the means by which the technology is delivered to the target or by which the target is incapacitated. ${ }^{292}$ For example, kinetic-energy technologies are one of the more commonly known forms of nonlethal weapons that domestic law enforcement often uses. ${ }^{293}$ Weapons such as police batons, water cannons, and rubber bullets fall into this category. ${ }^{294}$ Additionally, chemical and biological technologies can be used as nonlethal weapons. Chemical nonlethal weapons such as pepper spray have been widely used for some time; ${ }^{295}$ other chemical nonlethal

287. David P. Fidler, The International Legal Implications of "Non-Lethal Weapons," 21 MicH. J. INT'L. L. 51, 55 (1999).

288. Id. (citing John B. AleXander, Future War: NON-Lethal Weapons in MOdern WARFARE 1 (1999)).

289. James C. Duncan, A Primer on the Employment of Non-Lethal Weapons, 45 NAVAL L. REV. 1, 5 (1998).

290. See Hummer, supra note 285, at 134.

291. Fidler, supra note 287, at 59.

292. Id. at 60; see Lewer \& Davison, supra note 284, at 38 tbl. 1.

293. See Lewer \& Davison, supra note 284, at 40.

294. Id. at 38 .

295. Hummer, supra note 285, at 135 (noting that no other nonlethal weapon is used by more police departments and that police departments began experimenting with pepper spray in the early 
weapons focus on destroying crops, structures, or vehicles. ${ }^{296}$ Biological nonlethal weapons are less likely to be developed and converted for use by domestic law enforcement because the international Biological Weapons Convention (BWC) bans the development and production of biological weapons. ${ }^{297}$ Furthermore, the BWC does not make a distinction between nonlethal and lethal biological weapons. ${ }^{298}$

There has been a noteworthy amount of research into the use of sound waves as an acoustic nonlethal weapon. ${ }^{299}$ Sound has been used as a rudimentary nonlethal weapon in well-known situations. For example, the U.S. military used loud music to drive General Manuel Noriega out of his refuge without resorting to more destructive means. ${ }^{300}$ More technologically advanced uses of sound waves as nonlethal weapons are being developed. The Long Range Acoustic Device (LRAD) and similar sound canons, deployed by the U.S. Navy, Britain, Israel, and the Pittsburgh police department, have been used to repel adversaries and disperse crowds. ${ }^{301}$ The LRAD's intended use, however, is to "deliver audible warning messages over long ranges" and act as a hailing device. $^{302}$ Indeed, the Department of Defense has categorized the LRAD as a communications device almost certainly because its use as a weapon can cause permanent damage to the target's hearing. ${ }^{303}$

Still other research has been focused on the development of a "sound gun" that would emit a focused beam of sound intended to disorient the target. $^{304}$ The device would disrupt the balance system of the inner ear, causing the disorientation. ${ }^{305}$ Because of the risk of permanent hearing damage that acoustic nonlethal weapons pose and the limited potential

1990s).

296. Lewer \& Davison, supra note 284, at 38 tbl. 1.

297. Convention on the Prohibition of the Development, Production and Stockpiling of Bacteriological (Biological) and Toxin Weapons and on Their Destruction, Feb. 25, 1972, 26 U.S.T. 583 [hereinafter BWC]; NeIL DAVISON, 'NON-LeTHAL' WEAPONS 30 (Jim Whitman ed., 2009) (citing BWC, supra).

298. See DAVISON, supra note 297, at 30 (citing BWC, supra note 297).

299. Id. at $186-205$.

300. Teresa A. Meade, A History of Modern Latin America 301 (2010)

301. David A. Koplow, Nonlethal Weapons 20 (2006); Marco Evers, The Weapon of Sound: Sonic Canon Gives Pirates an Earful, SPIEgEL ONLine InT'L (Nov. 15, 2005), http://www.spiegel.de/international/spiegel/0,1518,385048,00.html; Ian Urbina, Protestors Are Met by Tear Gas at G-20 Conference, N.Y. TIMES, Sept. 24, 2009, at A10.

302. DAVISON, supra note 297, at 197; Lewer \& Davison, supra note 284, at 41.

303. DAVISON, supra note 297, at 197-98.

304. ROBERT L. SNOW, TECHNOLOGY AND LAW ENFORCEMENT 92 (2007).

305. Id. 
for incapacitation, their widespread development and deployment by domestic police departments seems unlikely. ${ }^{306}$ The two nonlethalweapon technologies upon which this Article will focus, electrical and directed energy, appear to be the most advanced technologies available to domestic law-enforcement.

\section{B. Directed-Energy Nonlethal Weapons}

Directed-energy weapons, as defined by the Department of Defense, are those weapons that produce a beam of "“concentrated electromagnetic energy or atomic or subatomic particles.”,307 The U.S. military considers these sorts of weapons part of their "electronic warfare" capabilities, as they involve "the use of electromagnetic and directed energy to control the electromagnetic spectrum or to attack the enemy."308 A commonly known electromagnetic-energy weapon is the millimeter wave used by the U. S. military's Active Denial System. ${ }^{309}$ The use of electromagnetic energy as a nonlethal weapon, however, also includes the deployment of high-power microwaves, low-power diode lasers, or high-energy chemical lasers. ${ }^{310}$ These sorts of electromagnetic energy can be classified into two groups: (1) "lasers [that] operat[e] in the visible, ultraviolet, or infrared part of the [electromagnetic] spectrum" and (2) "radio frequenc[ies], microwave[s], and millimet[er] wave beams."311

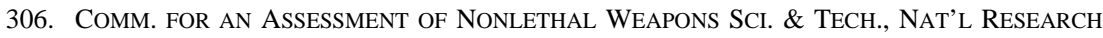

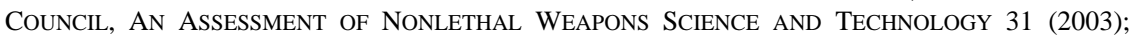
DAVISON, supra note 297, at 204. In addition, other acoustic nonlethal weapons, while not directed at the target's hearing, would resonate with body organs potentially causing physical damage. Lewer \& Davison, supra note 284, at 42.

307. DAVIson, supra note 297, at 143 (quoting U.S. DEP’T OF DEF., DictionaRY OF MiLITARY AND Associated TERMS 103 (2011), available at http://www.dtic.mil/doctrine/new_pubs/jp1_ 02.pdf).

308. Duncan, supra note 289, at 7 n.22 (citing Memorandum of Policy No. 6 on Electronic Warfare from Chairman, Joint Chiefs of Staff 1. (1993)).

309. See DAvison, supra note 297 at 166-72 (describing the Active Denial System and millimeter waves); see infra Part III.B.2.

310. Lewer \& Davison, supra note 284, at 42.

311. DAVISON, supra note 297, at 143 (footnote omitted). 


\section{Lasers}

The U. S. military has focused on the development and use of lasers as weapons since their discovery in $1960 .{ }^{312}$ During the 1980s, the military specifically focused on laser technology that would permanently blind a human target. $^{313}$ In 1995, however, ratification of Protocol on Blinding Laser Weapons to the 1980 Convention on Conventional Weapons limited the military's potential development of new laser weapons. $^{314}$ Since 1995, research has continued into the development of "dazzling" lasers, or lasers that only temporarily blind the target, although several problems have arisen. ${ }^{315}$ For example, some dazzler prototypes were safe at point-blank range but difficult to deploy against a moving target, while others were only safe for a quarter of a second. ${ }^{316}$

In July 2010, however, Laser Energetics, Inc., announced that it would manufacture the Dazer Laser for intended distribution to police departments and other agencies in the United States. ${ }^{317}$ The Dazer Laser emits a green laser that is intended to temporarily impair the target's vision. ${ }^{318}$ In addition to temporary blindness, the target's "equilibrium and awareness is impaired," which can cause feelings of nausea similar to motion sickness, as the manufacturer reports. ${ }^{319}$ These symptoms begin almost immediately and can last seconds or "hours depending on the [target's] physiology." ${ }^{\text {„20 }}$ The Dazer Laser, according to the

312. Id. at 146.

313. Id. at 147 (citing Bengt ANDERBERg \& Myron L. Wolbarsht, LASER WeApons: THE DAWN OF A NEW MiLiTARY AGE 144 (1992)).

314. Protocol on Blinding Laser Weapons (Protocol IV), Convention on Prohibitions or Restrictions on the Use of Certain Conventional Weapons Which May Be Deemed to Be Excessively Injurious or to Have Indiscriminate Effects, Oct. 13, 1995, 35 I.L.M. 1218.

315. See DAVISON, supra note 297, at 149.

316. Id. at $150-51$.

317. Linda Byron, Blinding Laser Beam Newest Police Tool, King5.COM (Jul. 22, 2010, 8:05 AM), http://www.king5.com/news/blinding-laser-beam-newest-police-tool-98973794.html. Israel's Department of Corrections has already agreed to buy the Dazer Laser for use as part of a pilot program within the prison system. Laser Energetics Sells Dazer Lasers ${ }^{\circledR}$ to Israel, GLOBE NEWSWIRE, Aug. 10, 2010, available at http://laserenergetics.com/pdf/Laser_Energetics_ Sells_Dazer_Lasers_to_Israel.pdf.

318. Frequently Asked Questions, LASER ENERGETICS, http://www.laserenergetics.com/ dazerlaser_generalquestions.htm (last visited Nov. 4, 2010).

319. Introduction, NON-LETHAL DEFENSES, http://www.non-lethaldefenses.com/intro.htm (last visited Nov. 4, 2010) [hereinafter Introduction, Non-LETHAL DEFENSES].

320. Id. 
manufacturer, is "safe at all ranges." "321 So long as it is operated within the manufacturer's suggested guidelines, no permanent ocular damage will occur even if the target is subjected to the laser multiple times. ${ }^{322}$

Other research has examined laser weapons' inducement of other nonlethal physiological responses. ${ }^{323}$ For example, the U.S. Army specifically created and funded the Stress and Motivated Behavior Institute (SMBI) at New Jersey Medical School in 2002 to study the neurobiology of stress and anxiety. ${ }^{324}$ The SMBI's charge, when it was created, was to develop new weapons to induce these feelings. ${ }^{325}$ To that end, the SMBI, along with various corporations and the U.S. Army, has been researching development of a nonlethal laser weapon that induces psychological and behavioral changes in the target. ${ }^{326}$ In addition, nonlethal weapon developers consider high-energy lasers a potential source for creating a kinetic shockwave through a laser-induced plasma. $^{327}$ The plasma creates an ultrasonic pressure wave that causes pain and temporary paralysis by stimulating the nerves in a human target's skin. ${ }^{328}$ Although the federal government reveals little about these sorts of nonlethal weapons, the Department of Defense budgeted approximately \$4 million per year between 2007 and 2009 for research into laser-induced plasma. ${ }^{329}$

\section{Radio Frequencies, Microwaves, and Millimeter Wave Beams}

As early as the 1980s, military scientists considered the possibility of using radar and similar electromagnetic spectrums in nonlethal, directedenergy weapons. ${ }^{330}$ The scientists hypothesized that these sorts of

\footnotetext{
321. Id.; Dazer Laser ${ }^{\circledR}$ Light Fighting Technologies: Independent Eye Safety Test, LASER ENERGETICS, http://www.laserenergetics.com/pdf/dazerlasereyesafetystudy.pdf (last visited Nov. 4, 2010).

322. Introduction, NON-LETHAL DEFENSES, supra note 319.

323. See DAVISON, supra note 297, at 155-56.

324. Id. at 155.

325. Id.

326. Id.

327. COMm. FOR AN Assessment OF NON-Lethal WeApons Sci. \& TeCH., supra note 306, at 30.

328. Id.

329. DAVISON, supra note 297, at 159.

330. Human Effects Advisory Panel, Penn State Applied Research Lab., A Narrative SumMARY AND INDEPENDENT ASSESSMENT OF THE ACTIVE DENIAL SYSTEM, JoINT NON-LETHAL WEAPONS PROGRAM 8-9 (2008), https://www.ncjrs.gov/pdffiles1/nij/grants/188262.pdf (last visited
} 
electromagnetic energy waves could repel human targets by stimulating the nerves in the target's skin. ${ }^{331}$ While a classified military program officially began in the early 1990s, the U.S. Air Force first announced its work toward developing the technology in 1998. ${ }^{332}$ In 2006, the Department of Defense announced its Active Denial System (ADS) and soon displayed it for media, government officials, and others. ${ }^{333}$

The Department of Defense describes the ADS as a "counterpersonnel, non-lethal, directed-energy weapon" that can be mounted on a military truck or jeep. ${ }^{334}$ It produces millimeter waves and uses an antenna to direct them toward the human target. ${ }^{335}$ When the millimeter wave energy strikes the target, it penetrates the skin approximately one sixty-fourth of an inch. ${ }^{336}$ The energy's effect on the skin's nerve endings causes "a heat sensation that within seconds becomes intolerable and forces the targeted individual to instinctively move."337 The heat sensation ceases when the energy stops striking the skin either because the operator turns it off or the target escapes the beam. ${ }^{338}$ The operator can select from four power levels between twenty-five and one hundred percent of the weapon's capacity and can deploy the weapon in bursts ranging in duration from one to six seconds. ${ }^{339}$ The Department of Defense reports that those who have been subjected to the ADS liken the experience to the wave of heat felt when opening a hot oven. ${ }^{340}$ Indeed, the feeling is so intense that the target's reflexive response of attempting to flee the beam acts as one of the safety features. ${ }^{341}$ According to the

Sept. 11, 2011) [hereinafter HEAP, PENN STATE]; Active Denial System Frequently Asked Questions, JOINT NON-LETHAL WEAPONS PROGRAM http://jalwp.defense.gov/pressroom/ faq_p2.html (last visited Oct. 6, 2011) [hereinafter ADS Frequently Asked Questions]; DAVISON, supra note 297, at 166-67.

331. HEAP, PENN STATE, supra note 330, at 9.

332. DAVISON, supra note 297, at 166-67.

333. Susan LeVine, Ctr. FOR Tech. \& NAT’l Sec. Policy, NAT’L Def. Univ., The Active Denial System: A Revolutionary, NON-LETHAL WeAPON FOR TODAY's BATTLEFIEld 10 (2009), available at http://www.ndu.edu/CTNSP/docUploaded/DTP\%2065\%20Active\%20 Defense\%20PO\%2060032.pdf.

334. Active Denial System (ADS) Fact Sheet, More Active Denial System Information 1-2, JoINT NON-LETHAL WEAPONS PROGRAM, www.kirtland.af.mil/shared/media/document/AFD-070404026.pdf (last visited Sept. 11, 2011) [hereinafter ADS Fact Sheet].

335. Id.

336. Id.

337. Id.

338. Id.

339. HEAP, PENN STATE, supra note 330, at 11.

340. ADS Frequently Asked Questions, supra note 330, at 4.

341. Id. at 2. 
Department of Defense, there is "minimal risk of injury because of the shallow penetration depth of energy into the skin at this short wavelength, the safety features designed into the system and normal human instinctive reactions." ${ }^{342}$ While the initial ADS prototype was a large device that must be mounted on a vehicle, the Department of Defense and the National Institute of Justice have invested in the research and development of a hand-held version. ${ }^{343}$ The goal is to create a shotgun-sized weapon that will generate the same sort of energy and have the same effect as the ADS. ${ }^{344}$

\section{Electrical Weapons}

While the genesis of nonlethal directed-energy weapons can be found in Department of Defense research and development, electrical nonlethal weapons have a more benign, yet also insidious, origin. ${ }^{345}$ As early as the 1930s in Argentina, electrical weapons evolved from farmers' use of cattle prods to herd animals into a torture device used during interrogations. ${ }^{346}$ Indeed, in the 1950s, police forces in the southern United States used "shock batons" as a pain-inducing device to disperse crowds. ${ }^{347}$ Current electrical nonlethal weapons, however, are dissimilar to these early iterations. ${ }^{348}$ Instead, domestic police departments use modern electrical nonlethal weapons, or electromuscular disruption (EMD) technology, for their effect on human sensory and motor functions. ${ }^{349}$

Modern EMD weapons, such as the Advanced Taser M-26 and Taser $\mathrm{X}-26$, emit 50,000 volts of electricity that affect the somatic nervous system by stimulating the body's motor nerves. ${ }^{350}$ Darts that attach to

\footnotetext{
342. ADS Fact Sheet, supra note 334.

343. DAVISON, supra note 297, at 170.

344. Id.

345. See id. at 21.

346. Id.

347. Id. (citing ReX APPlegate, RIOT CONTROL-MATERIALS AND TECHNIQUES 223 (1969).

348. Howard E. Williams, TASER ELECTRONIC CONTROL DEVICES AND SUDDEN IN-CUSTODY DEATH: SEPARATING EVIDENCE FROM CONJECTURE 19 (2008).

349. See id.

350. Id.; see also Bryan v. MacPherson, 630 F.3d 805, 825 n.4 (9th Cir. 2010) (“According to the manufacturer, this 50,000 volt charge is needed to ensure that the electrical current can 'jump' through the air or victim's clothing, thus completing a circuit. The manufacturer maintains, however, that the full 50,000 volts do not enter the victim's body; rather, it represents that the X26 delivers a peak voltage of 1,200 volts into the body.”).
} 
the target's skin or clothes deliver the voltage. ${ }^{351}$ The darts are attached to thin insulated wires, which are in turn attached to a device that generates the electricity. ${ }^{352}$ When the device is activated, the electrical stimulation of the body's motor nerves interferes with and impairs voluntary movement, causing involuntary muscle contractions and a loss of muscle control. ${ }^{353}$ The muscle contractions have been compared to those associated with strenuous activities such as weightlifting. ${ }^{354}$ Though their safety is contested, ${ }^{355}$ one study of 1,201 people who had been the target of a modern EMD weapon found that in ninety-nine percent of cases the weapon caused no or mild injuries. ${ }^{356}$ In those cases where there was an injury, the majority of the injuries were "superficial puncture wounds" from the darts embedding into the target's skin or blunt trauma from the target falling to the ground because of a loss of muscle control. $^{357}$ Nevertheless, while modern EMD weapons are not intended to be pain-compliance weapons, ${ }^{358}$ the targets of EMD weapons often describe the experience as excruciatingly painful. ${ }^{359}$ It is likely that any future EMD weapon will incapacitate a target in similar ways; however, several companies are developing weapons that can deliver the incapacitating shock by way of a laser-created ionized gas or plasma. ${ }^{360}$ By delivering the electricity through an ionized gas or plasma, the EMD and the operator need not rely on projectiles and wires to deliver the shock. ${ }^{361}$

\footnotetext{
351. KopLOW, supra note 301, at 16.

352. Id.

353. Id. at 16; WILLIAMS, supra note 348 , at 19-22.

354. WiLLIAMS, supra note 348, at 22.

355. While this Article does not focus on the safety of EMD weapons, it is important to note that there is significant dispute as to their safety. AMNESTY INT'L, UNITED STATES OF AMERICA: EXCESSIVE AND LETHAL FORCE? AMNESTY INTERNATIONAL'S CONCERNS ABOUT DEATHS AND ILLTREATMENT INVOLVING POLICE USE OF TASERS 7 (2004), available at www.hopenetworks.org/ Taser_report.pdf; KoPLOW, supra note 301, at 17; WilliAMS, supra note 348, at 19-24.

356. See William P. Bozeman et al., Safety and Injury Profile of Conducted Electrical Weapons Used by Law Enforcement Officers Against Criminal Suspects, 53 ANNALS EMERGENCY MED. 480, 484 (2009).

357. Id.

358. WiLLIAMS, supra note 348, at 19.

359. See Bryan v. MacPherson, 630 F.3d 805, 824 (9th Cir. 2010) (citing Lewis v. Downey, 581 F.3d 467, 475 (7th Cir. 2009)).

360. Lewer \& Davison, supra note 284, at 41.

361. See id.
} 


\section{Advances in Nonlethal Weapon Technology Require an Abandonment of the De Minimis Injury Exception}

While not constitutionally sound, a de minimis injury exception to Fourth Amendment excessive-force claims may seem commonsensical. Employing a de minimis injury exception appears to reduce potentially frivolous excessive-force claims by arrestees. In light of future nonlethal weapons on which police officers will likely rely to detain arrestees, however, a de minimis injury exception to such claims loses its luster. Indeed, if future nonlethal weapons are as enthusiastically adopted as the Taser, ${ }^{362}$ it is possible that police officers will almost exclusively rely on an arsenal of nonlethal devices to detain arrestees. For those circuits that permit district courts to employ a de minimis injury exception or require some more-than-insignificant quantum of injury, a citizen's right to be free from the state's use of excessive force could soon evaporate.

The future of nonlethal weapons lies in the development of devices that use pain, disorientation, temporary blindness, and perhaps even stress and anxiety to detain the target. The laudable goal is to avoid causing physical injury while seizing and arresting the target. With any confrontation between a police officer and an arrestee, however, there exists a possibility that the police officer will use more force than necessary to detain the citizen. If the de minimis injury exception is employed, those who are subjected to these future nonlethal weapons may have little recourse because of the lack of a cognizable injury. The temptation may arise for a district court judge, overwhelmed by a busy docket, to dismiss a case or grant summary judgment by relying on the arrestee's lack of injury while giving mere lip service to Graham. When police officers deploy new, cutting edge nonlethal weapons in the future, courts, like the district court in Wilkins, ${ }^{363}$ will have the opportunity to avoid difficult, constitutionally significant questions by focusing on the lack of injury the devices caused.

\footnotetext{
362. See Koplow, supra note 301, at 140 \& n.10 (citing Alex Berenson, As Police Use of Tasers Soars, Questions over Safety Emerge, N.Y. TIMES, July 18, 2004, at A1).

363. Wilkins v. Gaddy, 130 S. Ct. 1175, 1179 (2010) (“To conclude, as the District Court did here, that the absence of some 'arbitrary quantity of injury' requires automatic dismissal of an excessive force claim improperly bypasses [the nature of force] inquiry.” (quoting Hudson v. McMillian, 503 U.S. 1, 9 (1992))).
} 
Future nonlethal weapons that cause little or no physiological damage, however, will require courts to consider the effect on the target, beyond whether there was more than some undefined quantum of injury. Gone will be the days when police use a nightstick to subdue an arrestee. As the state's devices evolve, they will not cause the same sort of harm as a nightstick. If courts rely on an oversimplified de minimis injury exception, they may overlook the harm an arrestee sustains when a police officer uses excessive force. Instead, courts will need to consider whether the effects of a nonlethal weapon, while perhaps not easily quantified, were nonetheless more than was necessary to subdue the arrestee.

For example, nonlethal weapons that cause temporary blindness may initially subdue an arrestee. The blindness caused, however, must only last as long as is necessary under the circumstances. ${ }^{364}$ Even where the arrestee's eyes are physically unharmed, the blindness may be no longer than is necessary in light of either the severity of the suspected crime or the threat the suspect poses to the safety of the officers or others. ${ }^{365}$ Similarly, future nonlethal weapons that are designed to cause stress or anxiety must not interfere with an arrestee's normal psychological behavior any longer than is necessary to subdue a suspect who is actively resisting arrest or attempting to evade arrest. ${ }^{366}$ Certainly, the infliction of the feeling one experiences when a hot oven is open is unnecessary beyond the point an arrestee no longer poses a safety threat. If little or no physiological injury or no substantial psychological injury ${ }^{367}$ occurs, then a court that employs the de minimis injury exception or considers the quantum of injury sustained by the arrestee could nonetheless dismiss a case for want of injury.

While requiring an indefinable quantum of injury is constitutionally deficient and impractical in light of future nonlethal weapons, the level of injury an arrestee sustains may nonetheless be relevant to excessiveforce claims. Indeed, the jury system may give proper consideration to

364. For the purposes of this Article, I assume that state and local governments will permit the use of these nonlethal weapons once developed and introduced to their police departments. The propriety of using each nonlethal weapon described herein is beyond the scope of this discussion.

365. See Graham v. Connor, 490 U.S. 386, 396 (1989) (citing Tennessee v. Garner, 471 U.S. 1, 8-9 (1984)).

366. See id. at 396 (citing Garner 471 U.S. at 8-9).

367. See Flores v. City of Palacios, 381 F.3d 391, 400-01 (5th Cir. 2004) (finding that substantial psychological injuries alone satisfy the injury element of a Fourth Amendment excessive force claim). 
the significance of an arrestee's injury. For example, a fact-finder may consider the extent of an arrestee's injury when making a credibility determination. ${ }^{368}$ When considering the facts of the arrest as presented by the arrestee and comparing them with those presented by the police officer, the jury may well consider the extent of the arrestee's injuries when evaluating the veracity of the competing stories. ${ }^{369}$ Similarly, if a fact-finder determines that the police officer used excessive force, then the fact-finder may consider the degree of physical or mental injury the arrestee sustained when apportioning damages. ${ }^{370}$ Under those circumstances, the fact-finder might decide that an arrestee incurred only minor injuries as a result of excessive force, thus necessitating a negligible damage award. Recognizing the fact-finder's function in this way ensures that free citizens who are subjected to excessive force, while perhaps not recovering a significant monetary award, will nonetheless have their constitutional rights vindicated.

\section{CONCLUSION}

More than two decades ago, the Supreme Court determined that the Fourth Amendment governs arrestees' excessive-force claims. ${ }^{371}$ The Court recognized that an analysis of the claim is rooted in what the very claim itself implies: the arresting police officer used more force than was necessary to make the arrest. ${ }^{372}$ Nevertheless, left to their own devices and not yet admonished by the Court, many circuit and district courts have included a review of the quantum of injury sustained by the arrestee. While some circuit and district courts require that an arrestee allege more than a de minimis injury to have a meritorious claim, still other courts - and, at times, the same courts - require allegations of a more significant injury depending on the underlying facts of the case. The requirement of a preset, yet obscure, quantum of injury, however, ignores a citizen's independent interest in being free from the state's use

\footnotetext{
368. See, e.g., id. at 1178 (noting that the amount of injury sustained by an arrestee may elucidate whether the force could have been thought necessary or may "provide some indication of the amount of force applied").

369. Smith v. Mensinger, 293 F.3d 641, 649 (3d Cir. 2002) (“A [jury] could ... conclude that [the plaintiff's] injuries were so minor that the defendant's account ... is more credible.”).

370. Cf. Restatement (SECOND) OF TORTS § $902 \mathrm{cmt}$. a (1965) ("Damages flow from an injury.”).

371. Graham, 490 U.S. at 388.

372. See id. at 395.
} 
of excessive force and results in a hodgepodge of tests and considerations only a contortionist could navigate.

In addition, the development and certain deployment of future nonlethal weapons by domestic police departments portends the practical difficulties of requiring some quantum of injury in Fourth Amendment excessive-force claims. While the future of nonlethal weapons lies in the development of instruments that can cause intense pain, emotional distress, or even blindness, these weapons are designed to leave little or no evidence of their use. Police officers who are outfitted with nonlethal weapons will rarely inflict the degree of harm necessary to overcome hurdles like the de minimis injury exception. As a result, arrestees subjected to "diabolic or inhuman"373 force may very well find no judicial recourse when subjected to nonlethal weapons whose very purpose is to cause no evident injury. The Supreme Court must reaffirm its decision in Graham and refocus Fourth Amendment excessive-force inquiries on whether the force the state used to detain a citizen was objectively reasonable under the circumstances. 